\title{
OPTIMIZING WHEAT YIELD AND WATER PRODUCTIVITY USING AQUACROP AND APSIM-WHEAT MODELS IN NORTH NILE DELTA, EGYPT
}

\author{
A.M.S. Kheir, M.G. Zoghdan, M.A. Aiad and Sahar H. Rashed \\ Agricultural Research Center; Soils, Water and Environment Research Institute;9 \\ Cairo University Street, Giza, Egypt
}

Received: Apr. 2, 2018

Accepted: May 2, 2018

\begin{abstract}
The calibration of APSIM-Wheat and AQUACROP models had been done manually for anthesis date, maturity date, grain yield and total biomass of one recent spring wheat cultivar ( $T$. aestivum) under irrigated conditions in Egypt. Various treatments of planting dates, irrigation and fertilization were applied during two successive growing seasons of 2014/2015 and 2015/2016 in a split split plot design replicated three times. The calibration of APSIM-Wheat and AQUACROP was done for Misr3 cultivar using genetic parameters based on observed field data. Both models simulated anthesis, maturity dates, grain yield and total biomass accurately, with high values of determination coefficient $\left(R^{2}\right)$, and $D$-index greater than 0.8 as well as lower values of root mean square deviation (RMSD) in most cases. The calibrated models were then employed to explore wheat yield and water productivity in response to irrigation and nitrogen fertilization options. Scenarios analysis indicated that water productivity and yield of wheat ranged from (1.2-2.0 $\left.\mathrm{kg} \mathrm{m}^{-3}\right)$ and (6.8-8.7 $\left.\mathrm{t} \mathrm{ha}^{-1}\right)$ respectively. Application of 0.8 from actual evapotranspiration along with $120 \%$ from recommended nitrogen dose was the best predicted scenario achieving the highest value of crop water productivity. Investigating the suitable option achieving the current wheat yield by farmers $\left(7.4 \mathrm{t} \mathrm{ha}^{-1}\right)$, models demonstrated that application of 1.4 from actual evapotranspiration with $80 \%$ from the recommended nitrogen dose was the best option to achieve this yield. At this point predicted water productivity was low and recorded $1.5 \mathrm{~kg} \mathrm{~m}^{-3}$. Quantifying wheat yield in all districts of the studied area was also predicted using both models. APSIMWheat and AQUACROP can be used to drive the best management strategies in terms of $\mathrm{N}$-fertilizer and water regime for wheat under Egyptian conditions.
\end{abstract}

Key words: Calibration, Quantification, Management, Scenarios, Water productivity

\section{INTRODUCTION}

Wheat is considered the most important crop in the world and Egypt. Irrigated wheat in Egypt represents most of the total wheat lands while the arid and semi-arid is the dominant climate. However, irrigation water resources are very limited. Hence, enhancing crop yield, and water productivity through using a suitable irrigation scheduling program is an urgent necessary. In addition, there is a relationship between irrigation and fertilization and their influence on yield production particularly in Egyptian soils which suffers from low fertility. Both water and nitrogen are exposed to losses by many methods if not managed well. So, it is important to find new strategies and scenarios that could improve crop yield and crop water productivity through enhancing nitrogen use efficiency and irrigation management. Compost is very beneficial as it can be used as a soil conditioner and a slow release nutrient source (Hargreaves et al., 2008; Sullivan et al., 2003; Sullivan et al., 2002). Depending on compost as a source of $\mathrm{N}$ instead of mineral $\mathbf{N}$ on organic and clean agriculture, the rate of $\mathrm{N}$ mineralization 
must be taken into consideration. The $\mathrm{N}$ mineralization in compost could be characterized mainly by the $\mathrm{C}: \mathrm{N}$ ratio, generally $C: N$ ratio less than $25: 1$ in compost refers to the release of mineral $\mathrm{N}$ because the gross mineralization is higher than the microbial immobilization of $\mathrm{N}$ (Franklin et al., 2015; Prasad, 2009). Providing a satisfactory way to study the complexed systems could be achieved mathematically by crop models (Holzworth et al., 2014). It is becoming an assessment tool for optimizing crop physiology and ecology (Dong et al., 2014). Different crop models have been assessed and enhanced before to predict the potential wheat under various environments among of them APES (Donatelli et al., 2002), APSIM (Keating et al., 2003), CERES (Ritchie et al., 1998), CROPGRO (Godwin and Singh, 1998), DSSAT (Basso et al., 2016; Jones et al., 2003) EPIC (Wang et al., 2012) and STICS (Brisson et al., 2003).

Crop models should be validated first in current locations before using in other areas. Using multi-models is very interested to select the appropriate model that could be used successfully to predict crop production at the specific location (Martre et al., 2015). Wheat crop growth and development could be predicted daily in easily steps by APSIMWheat. APSIM-Wheat has been developed from integration of the approaches used in previous APSIMWheat modules (Asseng et al., 1998a; Asseng et al., 1998b; Wang et al., 2003). APSIM-Wheat model was used and tested under different management strategies such as water deficit, $\mathrm{CO}_{2}$ levels, nitrogen fertilization and temperature (Asseng et al., 2004). The recent version of FAO AQUACROP model (Steduto et al., 2012) is a user friendly and easy to use in high accuracy and robustness, in addition it requires a relatively small number of parameters. AQUACROP has been tested well in different locations on the world
(Hsiao et al., 2009) and showed a good fitness on simulating $\mathrm{CC}$, biomass development, and grain yield of different cultivars of maize. Also, respecting irrigation management and crop response to deficit irrigation, AQUACROP has been evaluated and parameterized globally (Khoshravesh et al., 2013), to enhance the scheduling of deficit irrigation (Paredes et al., 2014), to assess increasing of crop production responding to agricultural field management (Mhizha et al., 2014), to evaluate and assess the impacts of climate change on crop yield as well as evaluating the water quality on crop yield (Kumar et al., 2014).

The assessment of APSIM-Wheat and AQUACROP models has not been implemented with wheat production in Egypt, particularly with evaluating the effects of agricultural management practices on yield and water productivity and optimizing these practices. In addition, crop and water productivity under water stress requires evaluation using different management scenarios. Therefore, the main objectives of this study could be summarized as: (i) to calibrate APSIM-Wheat and AQUACROP models for a recent wheat cultivar from CIMMYT in Egypt. (ii) to predict spring wheat yield subjected to $\mathrm{N}$-fertilizer and water interactions for maximizing water productivity. (ii i ) potential quantify of wheat yield in a big agricultural governorate of Egypt using these models.

\section{MATERIALS AND METHODS}

\section{Study location and soil properties:}

A field experiment was carried out at Sakha Agricultural Research Station, Kafr El-Sheikh Governorate (KFS), Sakha, Egypt (Fig. 1) during two successive wheat growing seasons of 2014/2015 and 2015/2016 on wheat cv. Misr3 (triticum 
aestivum). Soil type of the experimental site was clay textured, it is Egyptian alluvial soils and classified by soil taxonomy as order vertisol (Abdel Kawy and Ali, 2012). The preceding crop in both was maize. Soil samples at depths of 0-20, 20-40 and 40-60 cm were taken before treatments application in both seasons according to the methods described by (Klute, 1986) (Tables 1\&2).

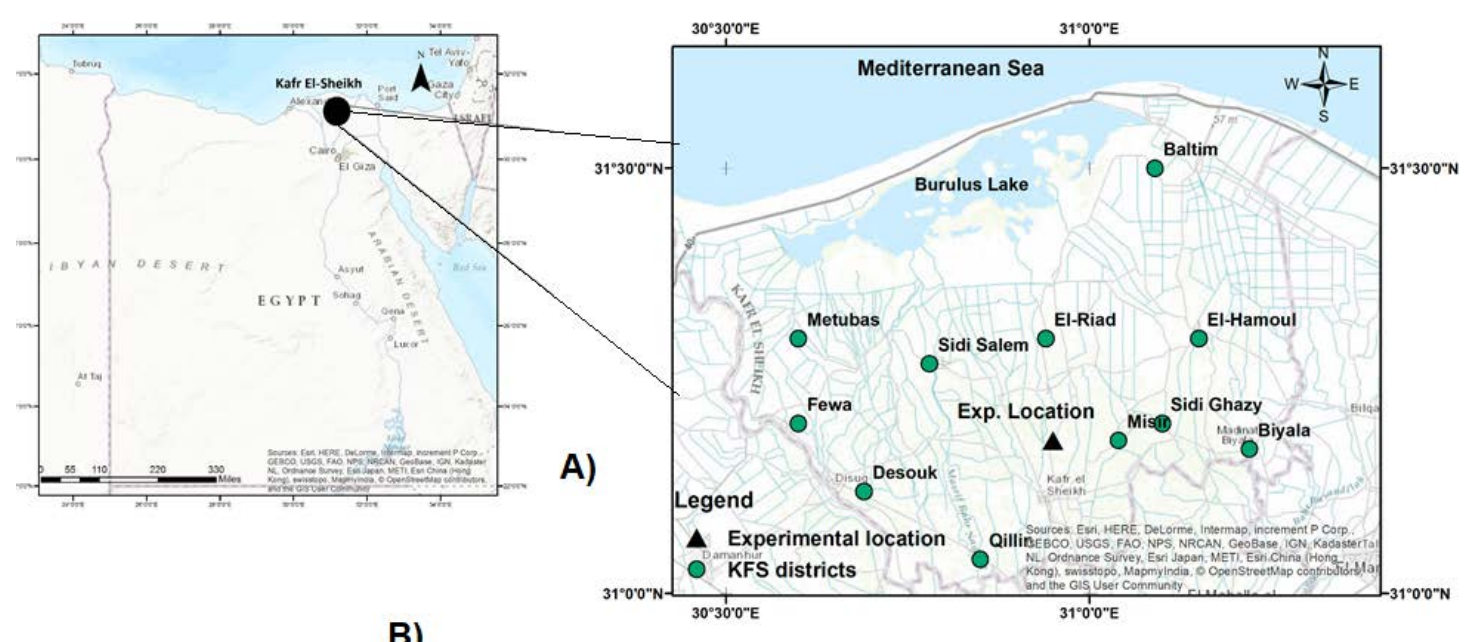

B)

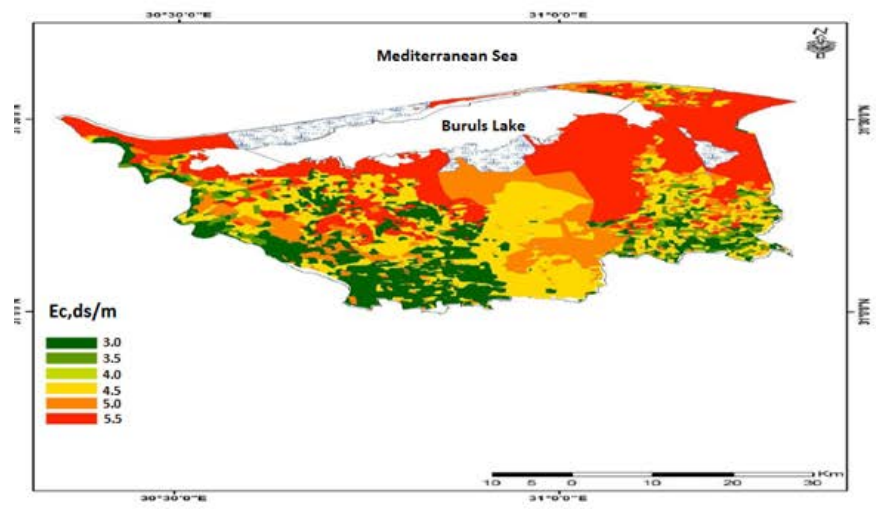

Fig. (1). Map of the studied area at River Nile North delta, Kafr El- Sheikh Governorate (A) and its soil salinity of the effective root zone (B).

Table (1): Soil physical properties of the studied soils before treatment application.

\begin{tabular}{|c|c|c|c|c|c|c|c|c|c|}
\hline \multirow[t]{2}{*}{$\begin{array}{l}\text { Soil Depth } \\
\text { (cm) }\end{array}$} & \multicolumn{3}{|c|}{$\begin{array}{c}\text { Particle size } \\
\text { distribution (\%) }\end{array}$} & \multirow[t]{2}{*}{$\begin{array}{l}\text { Texture } \\
\text { class }\end{array}$} & \multirow[t]{2}{*}{ O.M(\%) } & \multirow[t]{2}{*}{$\mathrm{CaCO}_{3}(\%)$} & \multicolumn{3}{|c|}{$\begin{array}{c}\text { Water constants } \\
\text { (\%) }\end{array}$} \\
\hline & Sand & Silt & Clay & & & & FC & WP & AW \\
\hline $0-20$ & 18.7 & 31.5 & 49.8 & clay & 1.54 & 2.56 & 42.9 & 22.9 & 20.0 \\
\hline $20-40$ & 15.7 & 32.6 & 51.7 & clay & 1.47 & 2.43 & 40.3 & 19.7 & 20.6 \\
\hline $40-60$ & 16.5 & 35.1 & 48.2 & caly & 1.13 & 2.08 & 38.8 & 18.9 & 19.9 \\
\hline
\end{tabular}

FC: field capacity; WP: wilting point; AW: available water 
A.M.S. Kheir, et al.,

Table (2): Soil chemical properties of the studied soils before treatment application.

\begin{tabular}{|c|c|c|c|c|c|c|c|c|c|c|c|c|c|c|}
\hline \multirow{2}{*}{$\begin{array}{c}\text { Soil } \\
\text { depth } \\
(\mathrm{cm})\end{array}$} & \multirow[t]{2}{*}{$\begin{array}{c}\mathrm{pH} \\
(1: 2.5)\end{array}$} & \multirow{2}{*}{$\begin{array}{c}\text { EC } \\
\text { (soil } \\
\text { paste } \\
\text { extract, } \\
\text { dS/m) }\end{array}$} & \multirow[t]{2}{*}{ SAR } & \multicolumn{4}{|c|}{$\begin{array}{l}\text { Soluble Cations } \\
\qquad\left(\mathrm{meq} \mathrm{I}^{-1}\right)\end{array}$} & \multicolumn{4}{|c|}{$\begin{array}{l}\text { Soluble Anions } \\
\qquad\left(\mathrm{meq}^{-1}\right)\end{array}$} & \multicolumn{3}{|c|}{$\begin{array}{c}\text { Available NPK } \\
\left(\mathrm{mg} \mathrm{kg} \mathrm{k}^{-1}\right)\end{array}$} \\
\hline & & & & $\mathrm{Na}^{+}$ & $\mathrm{K}^{+}$ & $\mathrm{Ca}^{+2}$ & $\mathrm{Mg}^{+2}$ & $\mathrm{CO}_{3}^{-2}$ & $\mathrm{HCO}_{3}{ }^{-}$ & $\mathrm{Cl}^{-}$ & $\mathrm{SO}_{4}^{-2}$ & $\mathbf{N}$ & P & K \\
\hline-20 & 8.12 & 3.18 & 9.43 & 21.6 & 0.7 & 6.7 & 3.8 & 0 & 2 & 18 & 12.8 & 62 & $\mid 10.71$ & 249 \\
\hline $20-40$ & 8.25 & 4.53 & 11.28 & 30.8 & 0.9 & 9.5 & 5.4 & 0 & 3.5 & 24 & 19.1 & 48 & 9.93 & 241 \\
\hline $40-60$ & 8.39 & 5.22 & 12.07 & 35.5 & 1.2 & 11 & 6.3 & 0 & 5.5 & 27 & 21.5 & 35 & 8.54 & 206 \\
\hline
\end{tabular}

\section{Agricultural practices and experimental design:}

This experiment was carried out in a split split plot design with three replicates. The main plots were assigned to planting dates; November, $1^{\text {th }}$ (early), November, $15^{\text {th }}$ (the recommended) and November, $30^{\text {th }}$ (late). Sub plots were irrigation treatments as a quantity from actual evapotranspiration $\left(E T_{c}\right)$ i.e. 1.5, 1.0 and $0.5 \mathrm{ET}_{\mathrm{c}}$. While, the sub sub plots were fertilization as a combination between mineral nitrogen as recommended by Ministry of Agricultural and Land Reclamation (MALR) which represents $120 \mathrm{~kg} \mathrm{~N} \mathrm{ha}^{-1}$ and compost as an organic fertilizer as:

1- Control (without mineral $\mathrm{N}$ fertilization and with 15 ton/ha of compost), "N0"

2- $100 \%$ from recommended $N(120 \mathrm{~kg}$ $\mathrm{N} / \mathrm{ha}$ ) with 9.2 ton /ha of compost, "N1"

3- $70 \%$ from recommended $\mathrm{N}$ with $\mathbf{1 1 . 5}$ ton/ha of compost, "N2"

4- $50 \%$ from recommended $\mathrm{N}$ with $\mathbf{1 3 . 8}$ ton/ha of compost, "N3"

The detailed analysis of the used compost is shown in Table 3.

A recent common high yield wheat cultivar (Misr 3) was chosen in this study. It is a modern variety added recently from The International Maize and Wheat Improvement Center (CIMMYT) to the Egyptian cultivars. Yield and phenology attributes such as grain yield, total final biomass, anthesis date (DAS) and maturity date (DAS) were measured and recorded. These parameters were then used to calibrate the used models under current conditions. Potential evapotranspiration was calculated from pan evaporation method and translated hereafter to actual evapotranspiration by multiplying the potential values of ET by crop coefficient $\left(\mathrm{K}_{\mathrm{c}}\right)$. Data were statistically analyzed using fisher's analysis of variance technique $(P \leq 0.01)$ in Sigma Plot version 13.0 from Systat Software, Inc., San Jose California USA, (www.systatsoftware.com). Where the F- test showed significant differences among means Least Significant Differences (LSD) test of 0.05 level of probability to compared means.

\section{Weather conditions:}

Data of daily maximum, minimum temperatures and solar radiation were obtained from an automated weather station in Sakha Agricultural Research Station, (Fig. 2). Sakha region is located at the first ecological zone in Egypt which characterizes by thermic soil temperature regime and torric soil moisture regime according to (USDA, 2010). Maximum temperature, minimum temperature and solar radiation through the wheat growing season ranged from $\left(15\right.$ to $\left.35{ }^{\circ} \mathrm{C}\right),\left(9\right.$ to $20^{\circ} \mathrm{C}$ ) and $(3$ to $22 \mathrm{MJ}$ $\mathrm{m}^{-2}$ day $^{-1}$ ) respectively, (Fig. 2). 
Table 3: The detailed chemical and nutritional analysis of the used compost, according to (Page et al., 1982).

\begin{tabular}{|c|c|}
\hline Characteristics & Values \\
\hline Dry weight $\left(\mathrm{kg} \mathrm{m}^{-3}\right)$ & 650.0 \\
\hline Moisture content (\%) & 26.80 \\
\hline Odour and colour & Acceptable and dark \\
\hline pH (1:10 compost-water suspension w/v) & 7.16 \\
\hline EC ( $1: 5$ compost - water extraction w/v, dS/m) & 4.76 \\
\hline Saturation percentage $\%$ (g/100g) & 175.0 \\
\hline CEC (cmole kg $\left.{ }^{-1}\right)$ & 64.34 \\
\hline Total organic - c \% & 25.5 \\
\hline Total organic matter \% & 43.96 \\
\hline $\mathrm{C} / \mathrm{N}$ ratio & 16.64 \\
\hline \multicolumn{2}{|c|}{ Total macro-nutrients \% } \\
\hline Total - nitrogen $\%$ & 1.79 \\
\hline Total - phosphorus \% & 1.68 \\
\hline Total-potassium $\%$ & 1.28 \\
\hline \multicolumn{2}{|c|}{ Available macro-nutrients ( $\mathrm{mg} \mathrm{kg}^{-1}$ compost) } \\
\hline Available - N (potassium sulfate) & 706 \\
\hline Available - P (0.5 $\left.\mathrm{M} \mathrm{NaHCO}_{3^{-}} \mathrm{pH} 8.5\right)$ & 50 \\
\hline Available - K (ammonium acetate pH 7) & 85 \\
\hline \multicolumn{2}{|c|}{ Available micro-nutrients ( $\mathrm{mg} \mathrm{kg}^{-1}$ compost) } \\
\hline Available - Fe & 450 \\
\hline Available - Mn & 100 \\
\hline Available - Zn & 35 \\
\hline Available - Cu & 135 \\
\hline \multicolumn{2}{|c|}{ Total micro-nutrients ( $\mathrm{mg} \mathrm{kg}^{-1}$ compost) } \\
\hline Total $-\mathrm{Fe}$ & 753 \\
\hline Total - Mn & 361 \\
\hline Total - Zn & 297 \\
\hline Total - Cu & 168 \\
\hline \multicolumn{2}{|c|}{ Available heavy metals ( $\mathrm{mg} \mathrm{kg}^{-1}$ compost) } \\
\hline Available - Cd & 13.2 \\
\hline Available - Ni & 62.7 \\
\hline Available - Pb & 120 \\
\hline
\end{tabular}




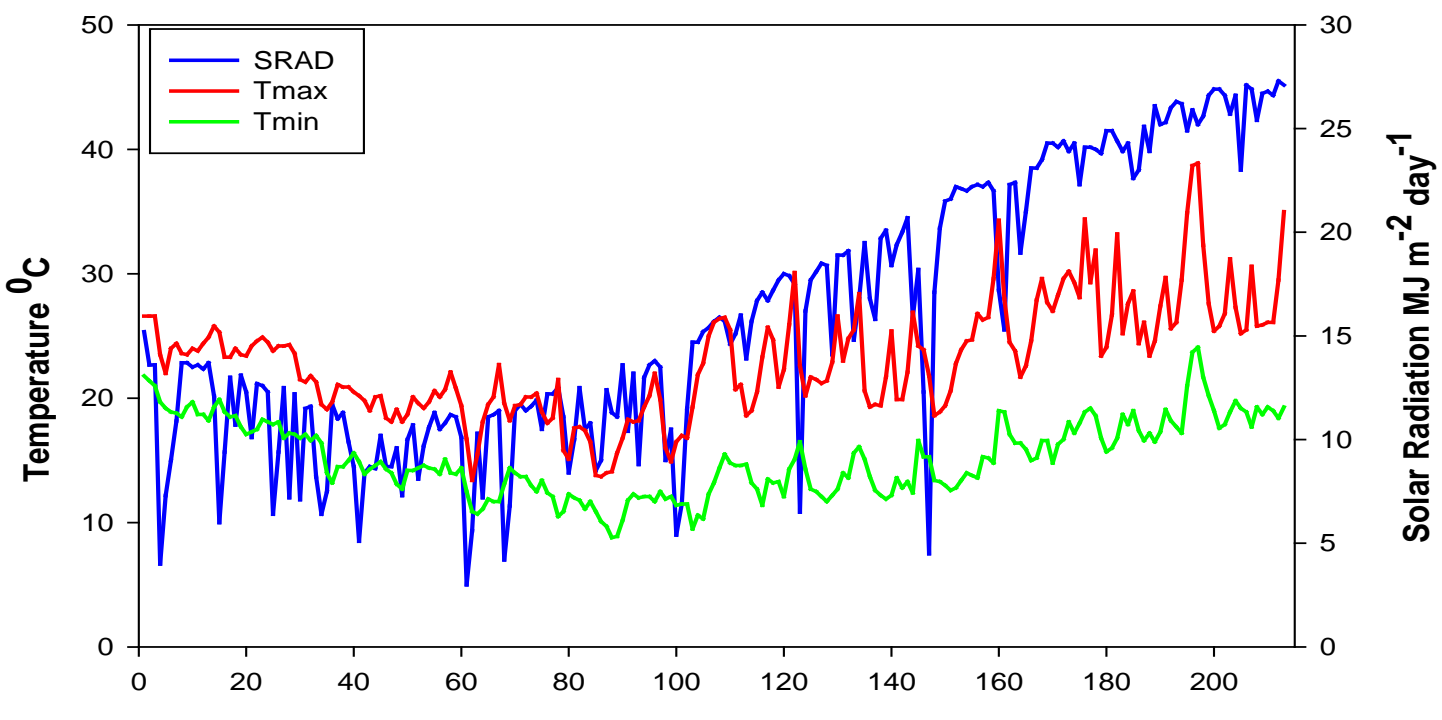

Days of growing seasons

Fig. (2). Daily maximum and minimum temperature $\left({ }^{\circ} \mathrm{C}\right)$ and solar radiation $\left(\mathrm{MJ} \mathrm{m} \mathrm{m}^{-2} \mathrm{day}^{-1}\right.$ ) data of Sakha as average of two growing seasons 2014/2015 and 2015/2016.

The required weather data for the other eleven districts in KFS governorate which are necessary for model predictions generated from NASA website (http://power.larc.nasa.gov/cgibin/cgiwrap/solar/agro.cgi?email=agrocli m@larc.nasa.gov) based on their coordinates, Fig.3.

\section{Water measurements:}

Soil water content was monitored using acquisition system composed by probes of Time Domain Reflectometry (TDR), (Heimovaara et al., 2004). Water productivity is used to define the relationship between crop produced and the amount of water involved in crop production (Ali and Talukder, 2008). Irrigation efficiency defined as ratio between water consumed by plant during the growing season (evapotranspiration) except effective rainfall and irrigation water applied.

\section{Modeling study:}

In this study, we used two models AQUACROP and APSIM-Wheat (Keating et al., 2003). These models were chosen because they are widely used and well accepted in the crop modelling community (Tubiello and Ewert, 2002). Nevertheless, they have not been seen or tested under the Egyptian conditions. These models were mainly used to extend the results for other locations in the same agro-climatic zone. Moreover, they are used to simulate different nitrogen and irrigation split scenarios. Both models are calibrated and tested with Misr 3 wheat cultivar in the current study. The calibration was done through checking the optimal set of parameters in models. The evaluation and performance of calibrated models have been done using coefficient of determination $\left(R^{2}\right)$, root mean square deviation (RMSD) and model index of agreement (d) as explained by (Jacovides and Kontoyiannis, 1995; Moriasi et al., 2007; Willmott, 1984). Following model calibration during two growing seasons, we applied different scenarios to predict the best water and $\mathrm{N}$ application practices that could achieve higher 
values of grain yield and WP. Scenarios included the following wide options $(0.5,0.6,0.7,0.8,0.9,1.0,1.1,1.2,1.3,1.4$ and $1.5 \mathrm{ET}_{\mathrm{c}}$ ) of the required crop water and $(50,60,70,80,90,100,110,120 \%$ from the recommended nitrogen fertilizer dose). After calibration and application of both models, they are used to predict wheat yield for all agricultural districts in Kafrelsheikh governorate.
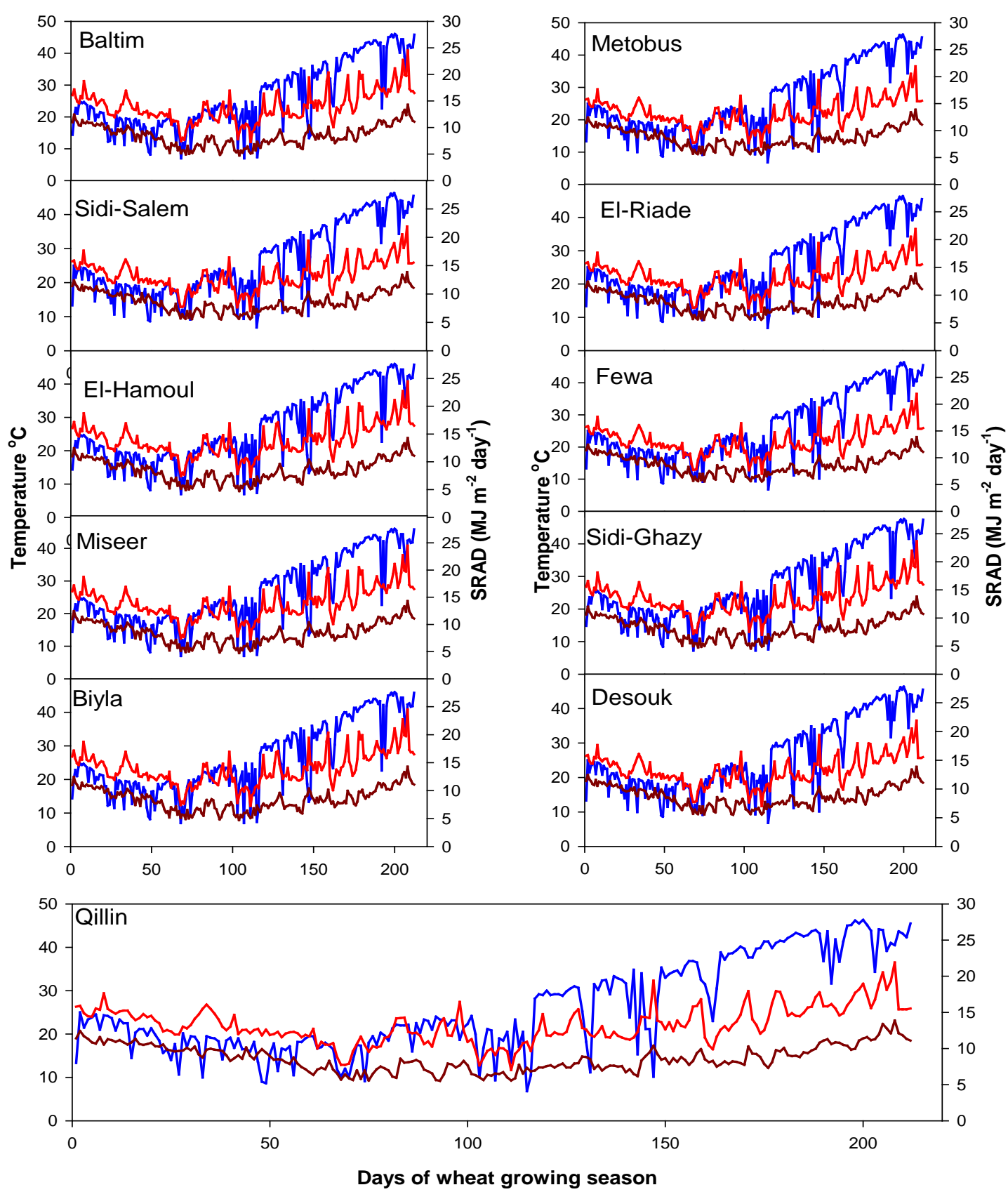

Fig. (3). Daily maximum and minimum temperature $\left({ }^{\circ} \mathrm{C}\right)$ and solar radiation $\left(\mathrm{MJ} \mathrm{m}^{-2}\right.$ day $\left.^{-1}\right)$ data of all studied districts in KFS. Data is required for yield predictions by the studied models. Colors of blue, red and dark red represent solar radiation, maximum and minimum temperatures respectively. 


\section{RESULTS AND DISCUSSION}

\section{Observed wheat yield and phenology :}

As shown in Figs. (4 and 5) that values of wheat grain yield and final biomass were higher under optimum planting date,P2 ( November, $15^{\text {th }}$ ), N1, and 12. The highest grain yield obtained was $8.1 \mathrm{t} \mathrm{ha}^{-1}$ achieving an increase by $55 \%$ comparing with the lowest grain yield $3.7 \mathrm{t} \mathrm{ha}^{-1}$ under early planting date (P1), deficit irrigation (I3) and without nitrogen fertilizer application (NO),(Fig.4). The final biomass increased also with optimum planting date (P2), fertilization (N1) and irrigation regime (12) achieving $16.5 \mathrm{t} \mathrm{ha}^{-1}$. Meanwhile, the lowest value $7.9 \mathrm{t} \mathrm{ha}^{-1}$ was noticed using deficit irrigation regime
(13), lately planting date (P3) and without adding nitrogen fertilizers (NO), (Fig.5). The higher yield under P2 is mainly due to the environmental conditions particularly temperature through the sensitive growth stage (Asseng et al., 2015). On the other hand, the lowest yield was noticed under P1(the first planting date,November, $1^{\text {th }}$ ), without any additions of nitrogen fertilizers as well as under extra irrigation (1.5 $\left.\mathrm{ET}_{\mathrm{c}}\right)$. The marked increase in wheat yields indicated clearly the vital role of $\mathbf{N}$ and compost in plant life and contribution for cell division and elongation. Statistical analysis in (Table 4) shows high significant effects of different treatments on wheat yield.

I1

12

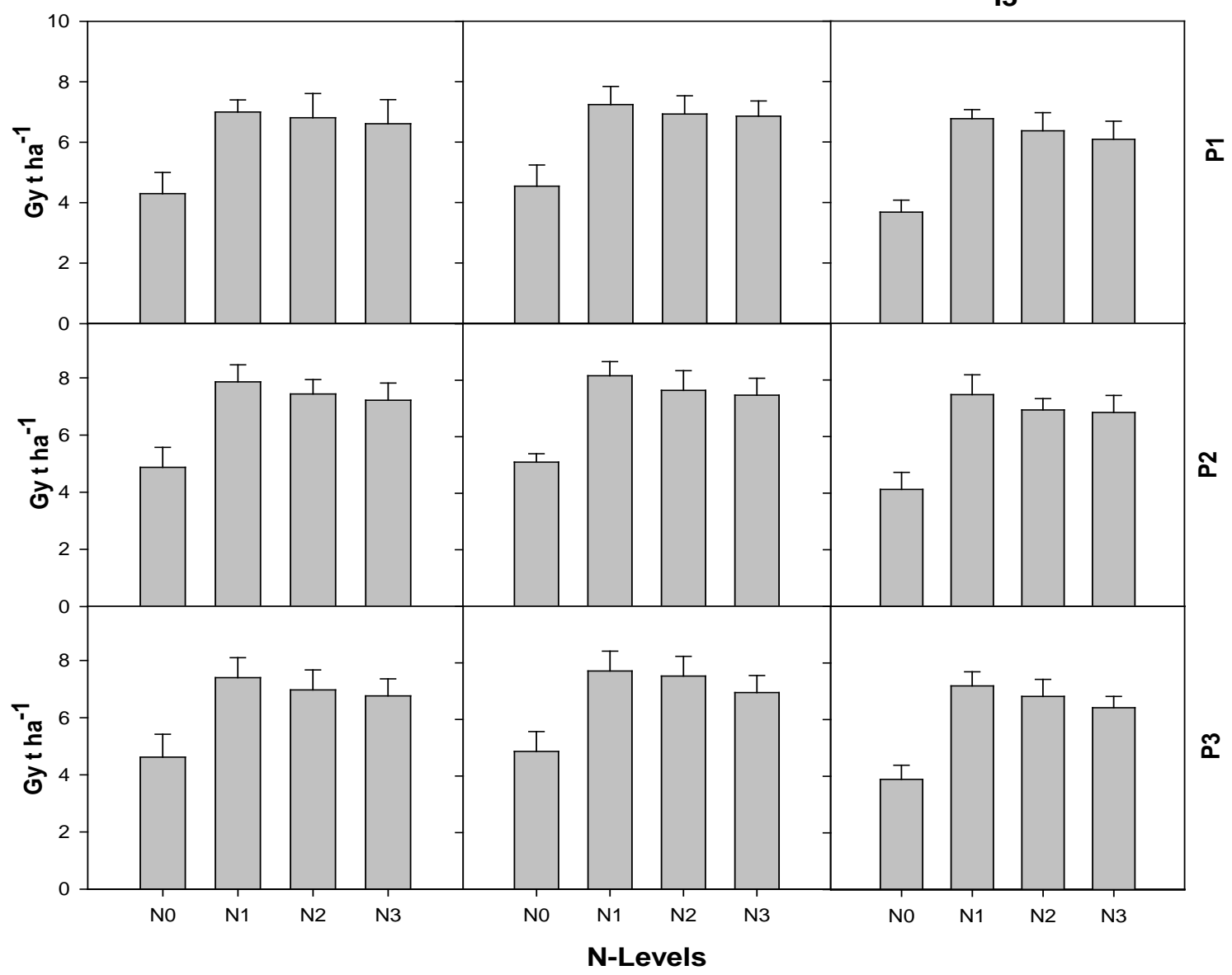

Fig. (4). Wheat grain yield as affected by irrigation, fertilization and planting dates (data represent the average of both seasons). 
I1

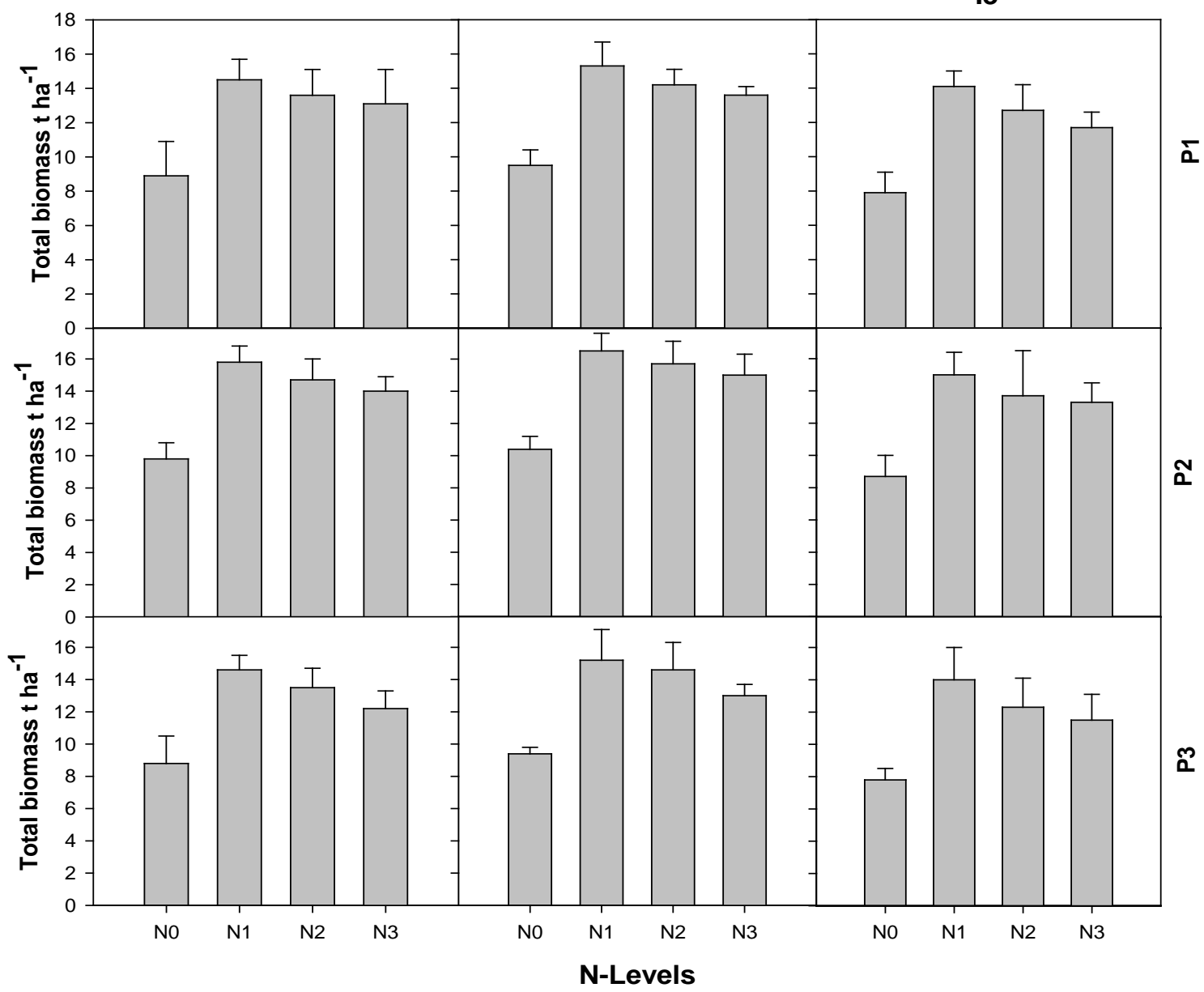

Fig. (5). Final total biomass of wheat (t/ha) as affected by irrigation, fertilization and planting dates, (data represent the average of both seasons).

Table (4): Main effects of planting dates, irrigation and fertilization on wheat grain and biomass yields, (data represent the average of two seasons).

\begin{tabular}{ccccccc}
\hline Grain Yield, $\mathrm{Kg} \mathrm{ha}^{-1}$ & & \multicolumn{4}{c}{ Total biomass, $\mathrm{kg} \mathrm{ha}^{-1}$} \\
\hline Levels & $\begin{array}{c}\text { Planting } \\
\text { dates }\end{array}$ & Irrigation & Nitrogen & $\begin{array}{c}\text { Planting } \\
\text { dates }\end{array}$ & Irrigation & Nitrogen \\
1 & 6100.2 & 6488.7 & 4444.9 & 12369.6 & 12740.9 & 9037.2 \\
2 & 6763.5 & 6750.5 & 7422.4 & 13577.3 & 13544.5 & 14943.4 \\
3 & 6427.4 & 6051.9 & 7052.1 & 12255.4 & 11916.9 & 13893.3 \\
4 & & & 6802.1 & & & 13062.5 \\
F-test & 225.14 & 254.93 & 2788.72 & 99.0 & 122.3 & 922.9 \\
L.S.D 0.05 & $* *$ & $* *$ & $* *$ & $* *$ & $* *$ & $* *$ \\
\hline
\end{tabular}


The phenological development of wheat from emergence passing by flowering to maturity is mainly affected by temperature, as well as day length and potential physiological stresses, (Olesen et al., 2012). Optimum planting date (P2), Irrigation (12) and fertilization (N1) achieved the highest value of anthesis (115 days) and maturity (144 days) as shown in Figs (6 and 7) respectively. This is mainly attributed to decreasing the mean temperature at these specific growth stages. Meanwhile, the lowest values were observed at 105 and 128 days for anthesis and maturity respectively under the first planting date
(P1), the third irrigation treatment (I3) and without mineral nitrogen fertilization (NO).

Increasing the yield and phenological stages in wheat under the optimum planting date, irrigation and fertilization is mainly due to the optimum environmental conditions, the role of $\mathrm{N}$ fertilization for cell division and elongation and the specific role of compost on increasing soil available water. Where, under P2 the values of available $\mathbf{N}$ after harvest as well as $\mathbf{N}$ uptake by whole plants were higher than those in P1 and P3 (Figs. 8 \& 9). In the same case errors as standard deviation in $\mathrm{P} 2$ were lower than those under $\mathrm{P} 1$ and P3, (Figs 4 to 7 ).

I1

12

13

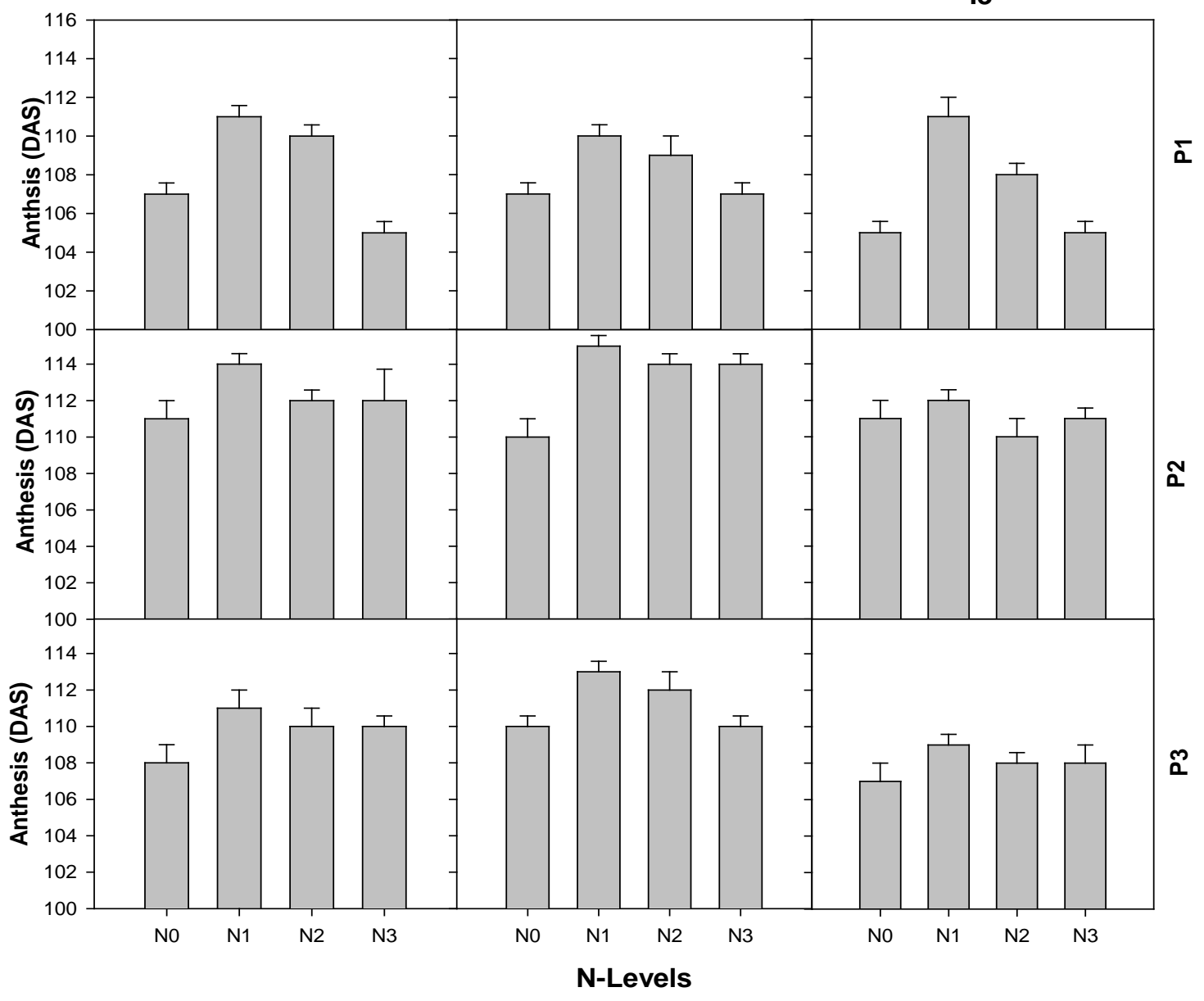

Fig.6. Anthesis date (DAS) as affected by irrigation, fertilization and planting dates. 


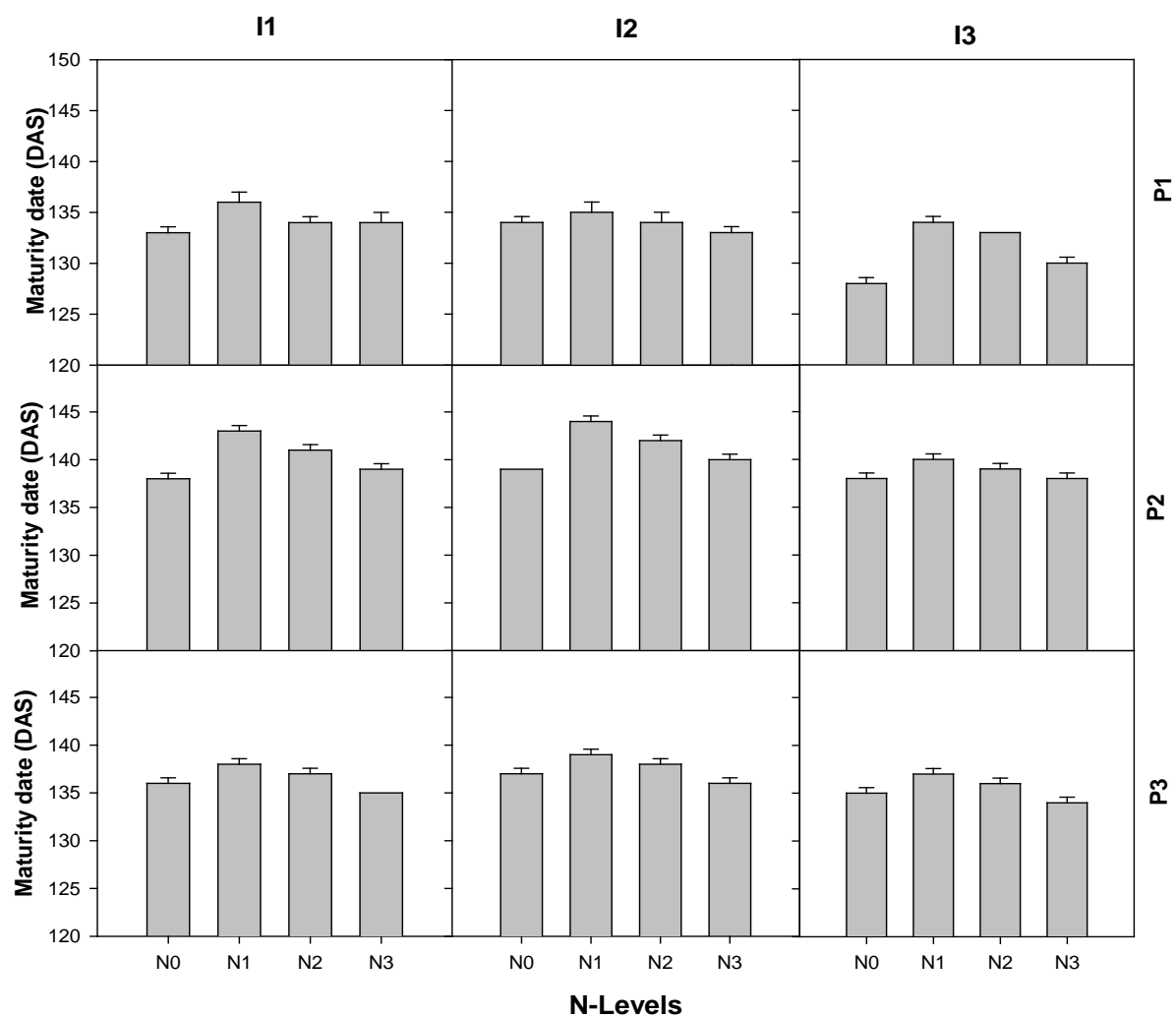

Fig. (7). Maturity date (DAS) as affected by irrigation, fertilization and planting dates, (data represent the average of both seasons).

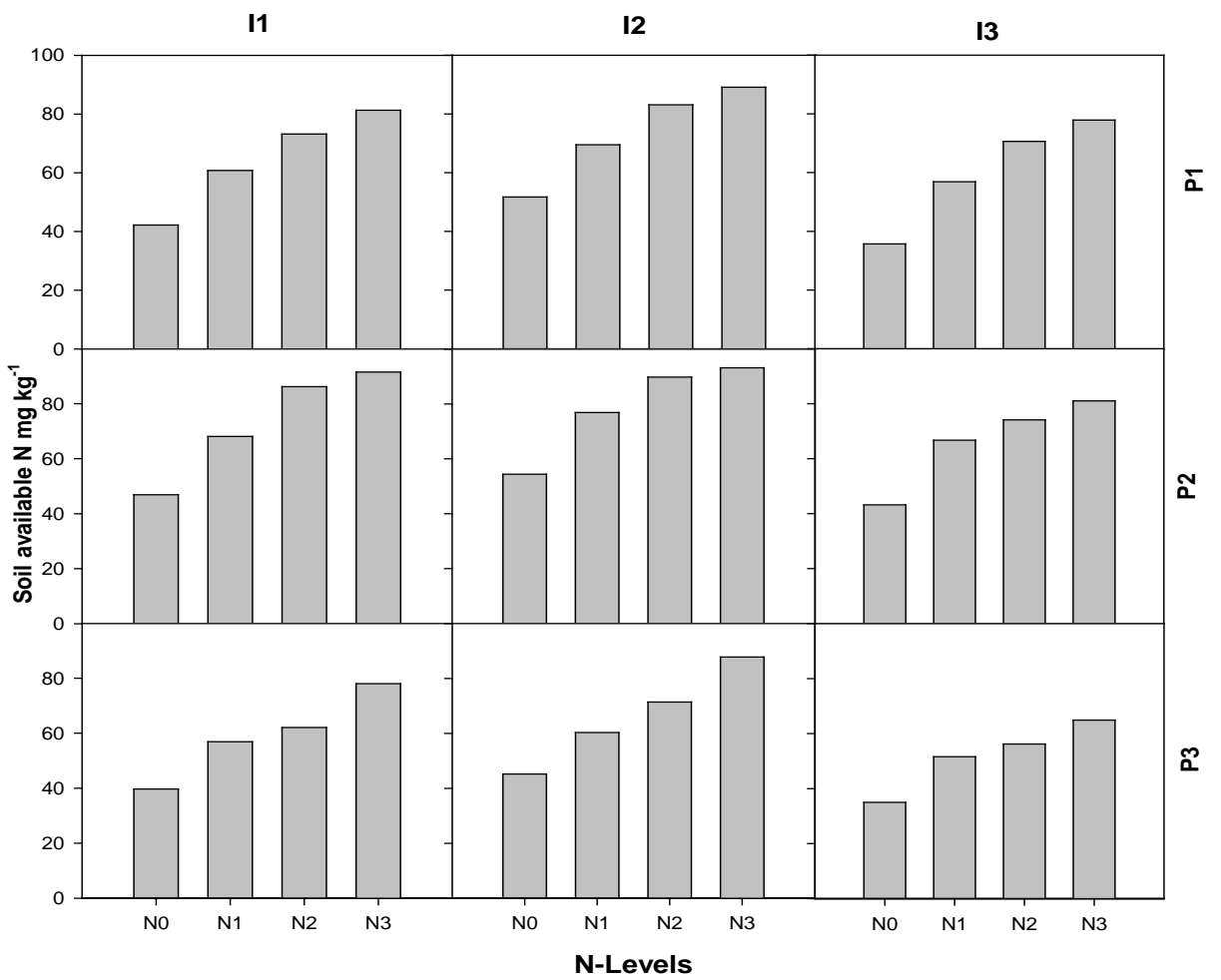

Fig. (8). Soil available mineral $\mathrm{N}$ remained in soil after wheat crop harvest, (data represent the average of both seasons). 


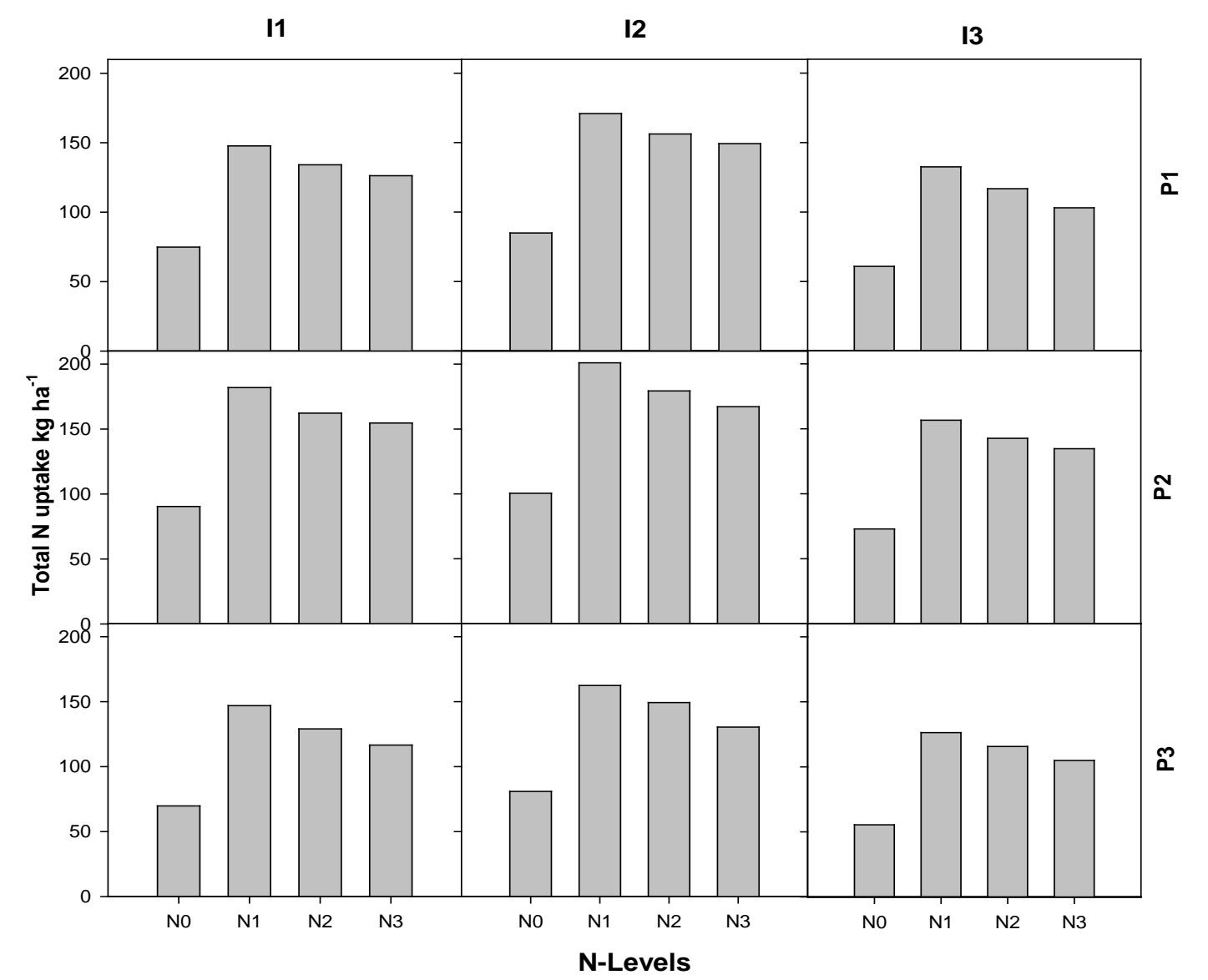

Fig. 9: Total $\mathrm{N}$ uptake in whole wheat under different treatments, (data represent the average of both seasons).

Referring to the contribution of compost on mineralization rates and the actual contribution of compost on $\mathrm{N}$ availability, data in (Fig. $10 \mathrm{~A}$ ) show that each one ton of compost can add about $0.7 \mathrm{~kg}$ of mineral $\mathrm{N}$. This value had been already deducted from the initial analysis of compost (Table. 3), where the available mineral $\mathrm{N}$ equal to $706 \mathrm{mg} \mathrm{kg}^{-1}$ of compost. Consequently, compost can add 10.5, 6.4, 8 and $9.7 \mathrm{~kg} \mathrm{~N} \mathrm{ha}^{-1}$ for the following treatments N0, N1, N2 and N3 respectively. Such values have been already added with those came from mineral fertilizer (Fig. 10 B).

\section{Wheat water productivity and water relations:}

Currently, the need to increase crop water productivity is very necessary, due to the limited water resources and population increase, (Kijne et al., 2003; Saad et al., 2014). The results showed that planting date, irrigation and fertilization affected on WP, (Fig. 11). The highest value of observed water productivity $\left(1.6 \mathrm{~kg} \mathrm{~m}^{-3}\right)$ was recorded under the second planting date (P2, the recommended), the second irrigation treatment (12) and with the first fertilizer treatment (N1). Meanwhile, the lowest value $\left(0.7 \mathrm{~kg} \mathrm{~m}^{-3}\right)$ was noticed under the first planting date, the third irrigation treatment and without applying nitrogen fertilization, NO (Fig. 11). This is mainly due to increasing crop life period and thus increasing mean seasonal irrigation water applied (Fig. 12 A)under early planting date (P1) as well as decreasing yield due to the unsuitable environmental 

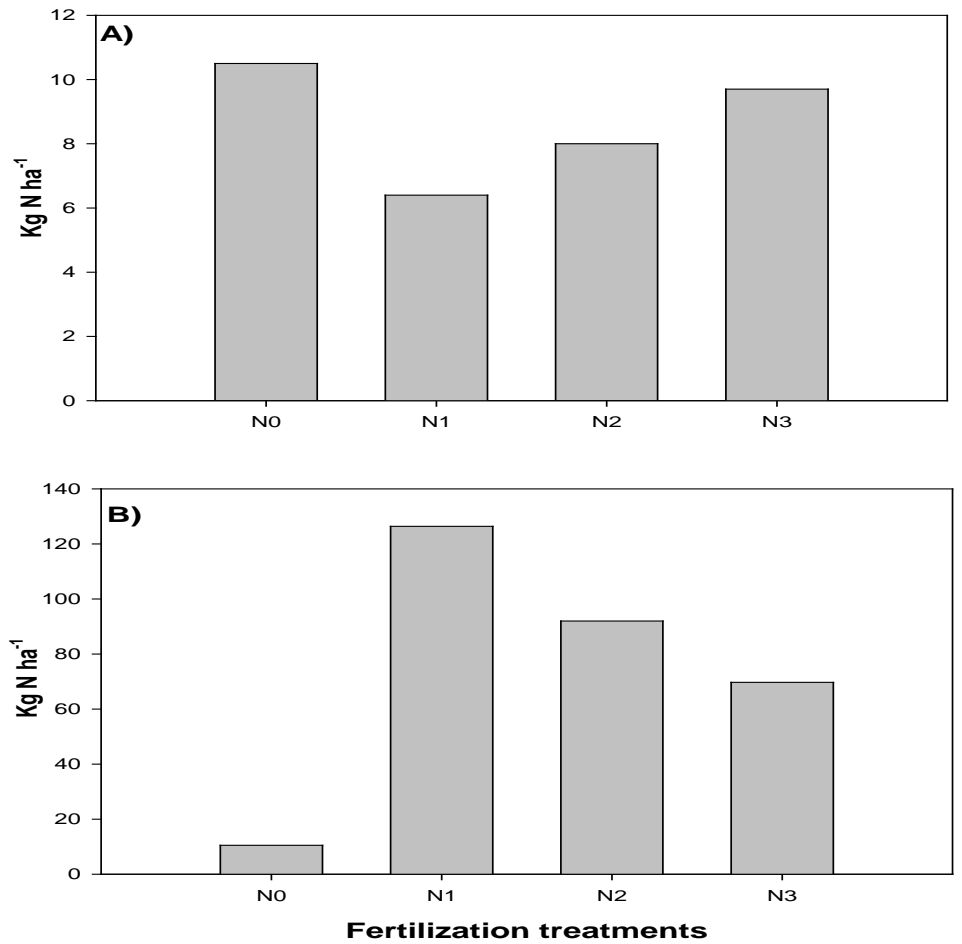

Fig. (10). The added mineral $N$ to soil from compost (A) and from both compost and mineral nitrogen fertilization $(B)$ under different treatments.

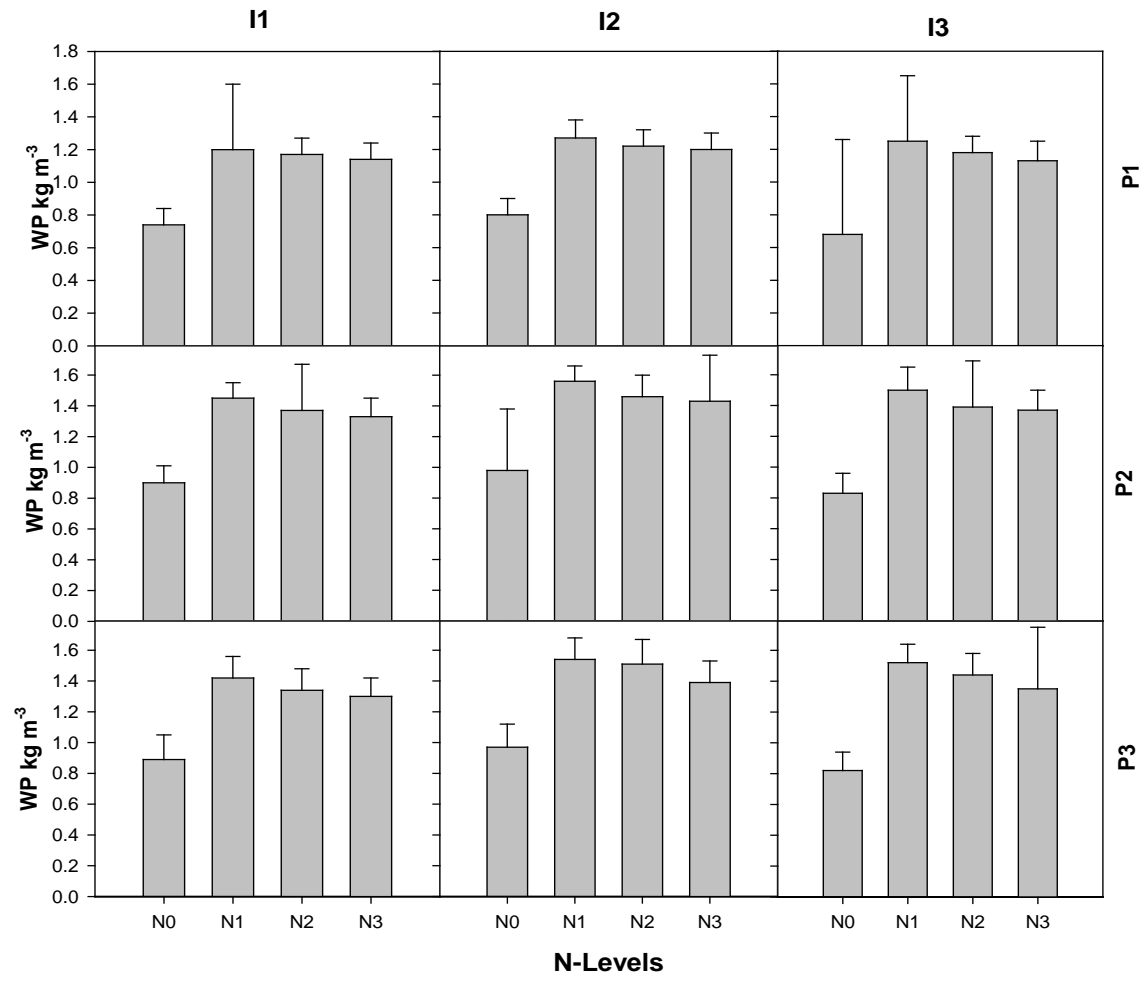

Fig. (11). Wheat water productivity as affected by irrigation, fertilization and planting dates, (data represent the average of both seasons). 

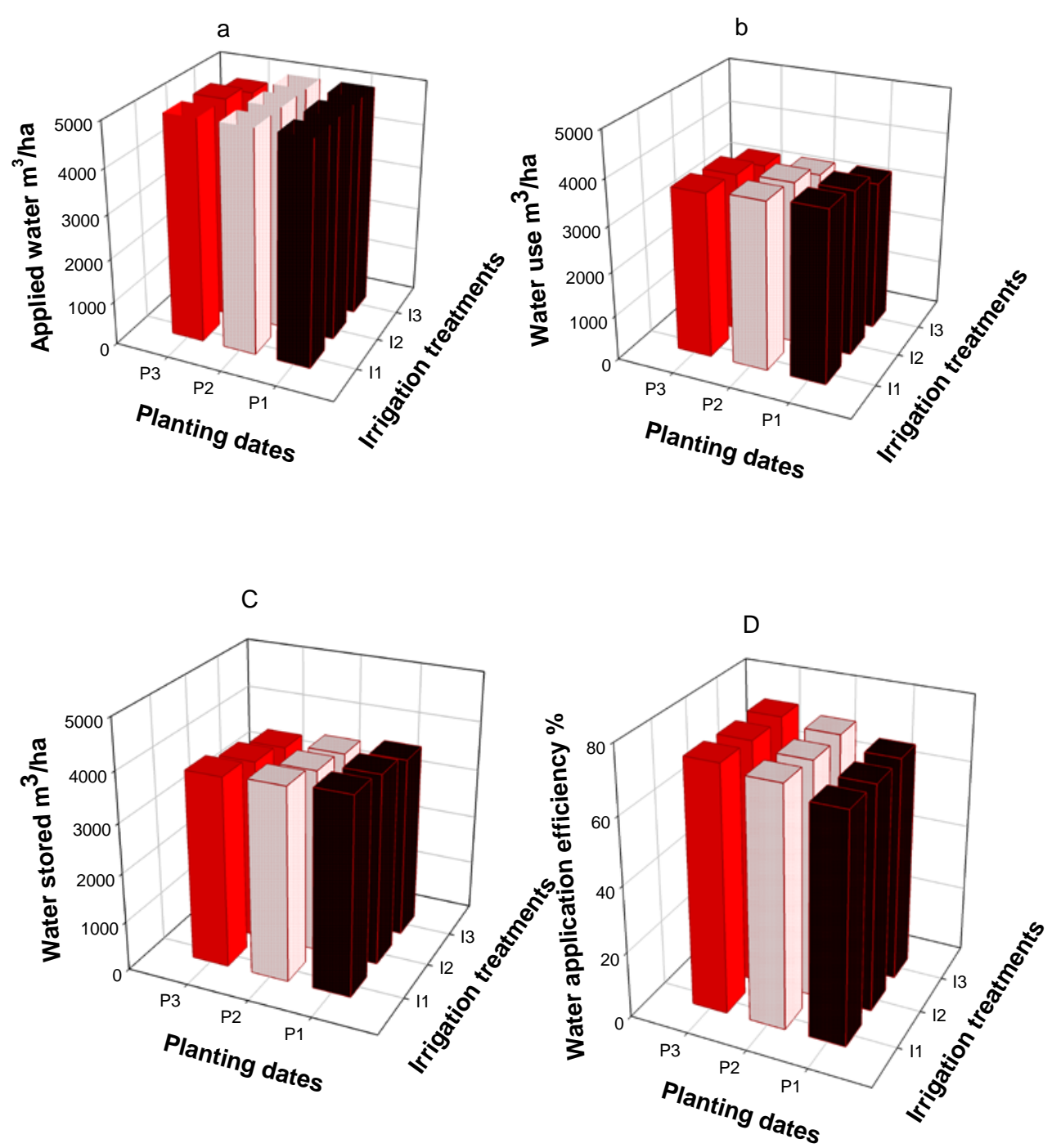

Fig. (12). Wheat water applied (a), use (b), stored(c) and application efficiency (d) as affected by irrigation, and planting dates.

conditions. Different studies have shown that wheat can be grown with deficit irrigation without significant yield reduction (Zhang et al., 1998). Similar to applied water, mean values of water use and water stored decreased with delaying planting dates from early to lately. Where, the highest values of water use and water stored were 3591.9 and $3826.5 \mathrm{~m}^{3} \mathrm{ha}^{-1}$ respectively under the first planting date (Fig.12). These values decreased gradually under delay planting dates. This is also a reason for decreasing water productivity in case of the first planting date. Water application efficiency appeared in an opposite trend, where the highest value was recorded $73.5 \%$ under the third planting date (P3) and decreased to $67.8 \%$ under the first planting date (P1) passed by $71.3 \%$ in case of the second planting date (Fig.12).

\section{Model calibrations:}

AQUACROP and APSIM- Wheat models were calibrated using the dataset of 2014/2015 and 2015/2016 growing seasons with Misr3 cultivar. The calibration had been done manually 
through modifying the cultivar parameters to agree with field dataset under all treatments. (Tables 5 and 6) supply the list of calibrated cultivar parameters for Misr3 for both used models. The coefficients were obtained step by step for this calibration. First, we started with phenological parameters, then with grain and biomass yields. The genetic parameters determination according to (Godwin and Singh, 1998) have been done manually. The values were modified based on reaching the minimum root mean square deviation (RMSD)between predicted and observed field data. (Fig. 13) shows that calibrations of AQUACROP and APSIM works well and robust. Where, the calibration of both models gave a high agreement of grain yield, total biomass, anthesis and maturity dates. Both crop models reproduced grain yields well with $\mathrm{R}^{2}$ 0.84. Also, $\mathrm{RMSD}$ values were 555 and $500 \mathrm{~kg} \mathrm{ha}^{-1}$ and high agreement index (d) 0.93 and 0.94 for AQUACROP and APSIM respectively (Table 7). Therefore, the models showed a high yield simulation under the current conditions. Also, total biomass simulations were predicted well under both models. Where, $\mathbf{R}^{2}$ values of simulated biomass were 0.96 and 0.84 , RMSD values were 309 and $613 \mathrm{~kg} \mathrm{ha}^{-1}$. In addition, (d) values were 0.99 and 0.97 for both AQUACROP and APSIM wheat respectively, (Table 7). Regarding the simulations of wheat phenology (anthesis and maturity), plotted data in (Fig. 13) and statistical indicators in (Table 7) showed a good agreement between simulated and observed values. Therefore, the outcomes from AQUACROP and APSIM-Wheat models in this study could be used successfully as a decision support tool to select the fit cultivars. As well known that wheat phenology has a high impact on yield growth and development (Ceglar et al., 2011). Anthesis and maturity dates were simulated well by both models (Fig.13 and Table 7). In APSIM-Wheat, anthesis date was calibrated using Vern_Sens and
Photo_Sens, meanwhile maturity date was controlled by $t t$ end_of Juvenile (Table 5). Therefore, we usually need to use these parameters for APSIM calibration (Ahmed et al., 2016; Asseng et al., 1998). While in case of AQUACROP anthesis and maturity dates could be modified and controlled by time to flowering and time to maturity (Table 5). Accurate phenology is considered the first priority for model calibration (Archontoulis et al., 2014). Due to achieving high accuracy and low uncertainty of phenology, the genotypic variations could be captured by models which affect yield, biomass and leaf area development (Robertson et al., 2002). Solar radiation interception (RI) and radiation use efficiency (RUE) are considered the main factors that can influence on biomass production. Our findings showed a high accuracy to predict total biomass similar to achieved by (Arora et al., 2007). Due to the correlation between biomass and grain yield (Dettori et al., 2011), simulations of biomass based on crop models are accurate and robust. In these results, biomass in APSIM-Wheat was determined using tt_floral_initiation (Table 6), meanwhile in AQUACROP it was controlled by plant density and maximum canopy cover (Table 5).

Grain yield is resulting from crop canopy and its $\mathrm{RI}, \mathrm{HI}$ and RUE. Both models achieved a high robust in simulating grain yield. In APSIM-Wheat, the parameters that responsible for determining grain yield are grain growth rate, maximum grain size, and potential rate of grain filling (Table 5). Meanwhile, in case of AQUACROP, harvest index is the required parameter for grain yield calibration. Therefore, by modifying these parameters grain yield of the specific cultivar could be increased or decreased, provided that it must be modified after process of crop phenology calibration (Ma et al., 2011). 
A.M.S. Kheir, et al.,

Table (5): Cultivar parameters of cv. Misr3 calibrated for AQUACROP model.

\begin{tabular}{lclc}
\hline Model & Parameter & Parameter definition & Misr3 \\
\hline \multirow{3}{*}{ AQUACROP } & HI & Harvest Index, \% & 48 \\
& TF & Time to flowering, day & 110 \\
& TM & Time to maturity, day & 145 \\
& PD & Plant density, plants ha ${ }^{-1}$ & 250000 \\
\hline
\end{tabular}

Table (6): Cultivar parameters of cv. Misr3 calibrated for APSIM-Wheat model.

\begin{tabular}{|c|c|c|}
\hline Name & Unit & Misr 3 \\
\hline Photo_Sens (Photoperiod sensitivity) & - & 3.7 \\
\hline Vern_Sens (Vernalization sensitivity) & - & 0 \\
\hline $\begin{array}{l}\text { tt_end_of_juvenile (thermal time needed from sowing to end } \\
\text { of juvenile) }\end{array}$ & ${ }^{\circ} \mathrm{C}$ days & 660 \\
\hline tt_flowering (thermal time needed in anthesis phase) & ${ }^{\circ} \mathrm{C}$ days & 175 \\
\hline $\begin{array}{l}\text { tt_floral_initiation (thermal time from start of grain filling to } \\
\text { maturity) }\end{array}$ & ${ }^{\circ} \mathrm{C}$ days & 910 \\
\hline $\begin{array}{l}\text { tt_start_grain_fill (thermal time from start of grain filling to } \\
\text { maturity) }\end{array}$ & ${ }^{\circ} \mathrm{C}$ days & 1000 \\
\hline Max_grain_size (maximum grain size) & g & 0.066 \\
\hline $\begin{array}{l}\text { Potential_grain_growth_rate (grain growth rate from } \\
\text { floering to grain filling) }\end{array}$ & g grain ${ }^{-1}$ day $^{-1}$ & 0.002 \\
\hline Potential_grain_filling rate (potential daily grain filling rate) & g grain ${ }^{-1}$ day $^{-1}$ & 0.007 \\
\hline $\begin{array}{l}\text { Grains_per_gram_stem (grain number per stem weight at } \\
\text { the start of grain filling }\end{array}$ & g & 60 \\
\hline
\end{tabular}

Table (7): Models evaluation indices of evaluating the performance of AQUACROP and APSIM-Wheat for Misr 3 spring wheat

\begin{tabular}{lllll}
\hline Models evaluation & \multicolumn{2}{l}{ AQUACROP model } & \multicolumn{2}{l}{ APSIM-Wheat model } \\
\cline { 2 - 5 } $\mathrm{R}^{2}$ & Grain yield & Total biomass & Grain yield & Total biomass \\
RMSD & 0.84 & 0.96 & 0.84 & 0.84 \\
$\mathrm{D}$ & $555 \mathrm{~kg} \mathrm{ha}^{-1}$ & $309 \mathrm{~kg} \mathrm{ha}^{-1}$ & $500 \mathrm{~kg} \mathrm{ha}^{-1}$ & $613 \mathrm{~kg} \mathrm{ha}^{-1}$ \\
& 0.93 & 0.99 & 0.94 & 0.97 \\
$\mathrm{R}^{2}$ & Anthesis & Maturity & Anthesis & Maturity \\
RMSD & 0.38 & 0.59 & 0.62 & 0.48 \\
$\mathrm{D}$ & 3 days & 3 days & 2 days & 3 days \\
\hline
\end{tabular}



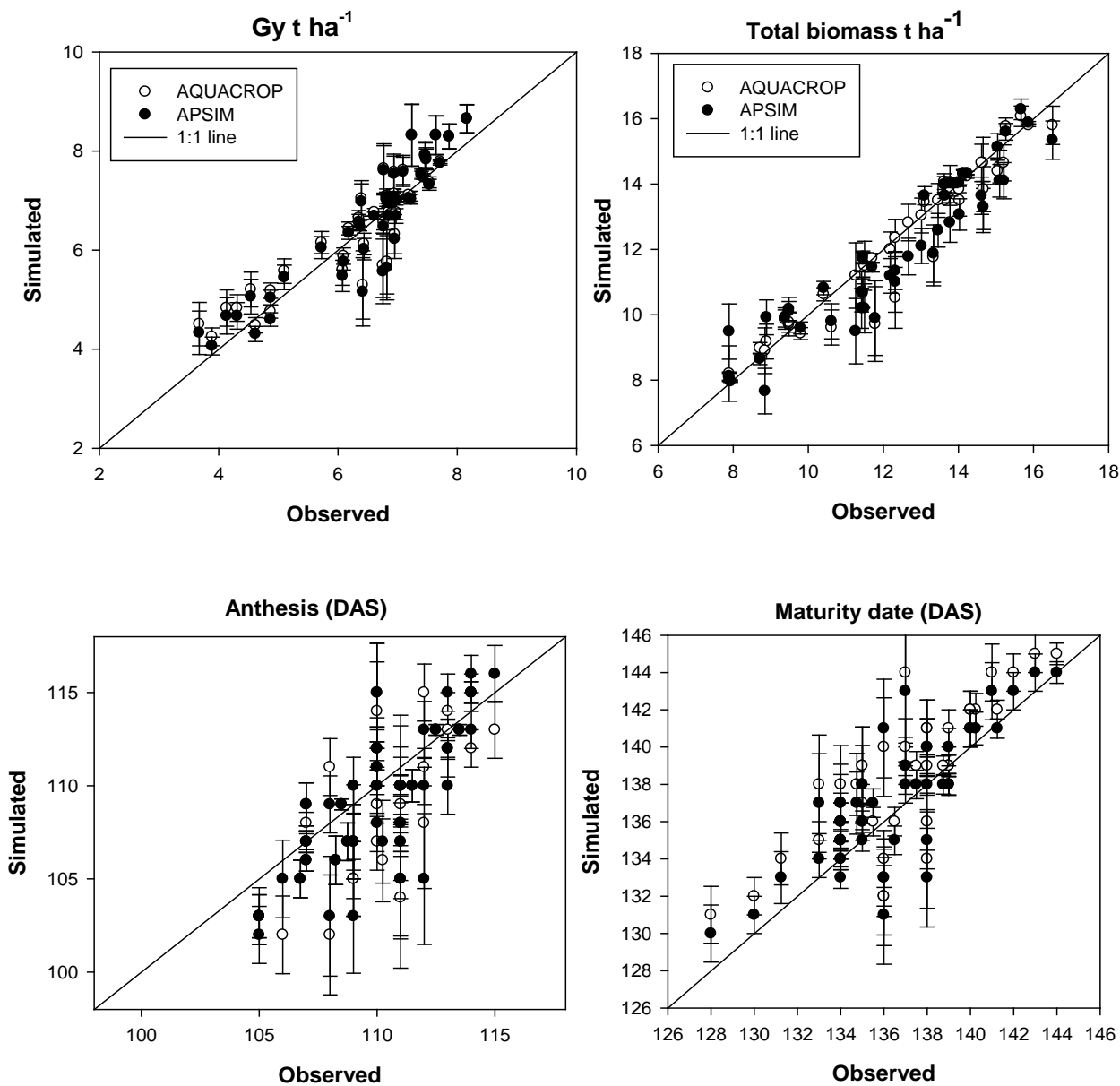

Fig. (13). Calibrations of AQUACROP (opened circles) and APSIM-Wheat (closed circles) models under different treatments (planting dates, irrigation and fertilization) in Sakha location. symbols, mean; (error bars, +l- 1 s.d.).

\section{Model applications:}

After model calibrations using various experimental dataset in the studied area, we used both models to predict GY and WP in response to various options of nitrogen and water as treatment inputs in crop models. This is to find out which scenario can maximize yield and water productivity. The data in (Figs 14 A \& B) show the predicted wheat yield and water productivity respectively under various scenarios of water regime and $\mathbf{N}$ fertilizer doses. Data showed that the highest yield $8.7 \mathrm{t} \mathrm{ha}^{-1}$ was predicted under $120 \%$ from recommended $\mathrm{N}$ in combination with irrigation by $1.2 \mathrm{ET}_{\mathrm{c}}$ (Fig.14 A). Meanwhile, the highest value of WP 2.0 $\mathrm{kg} \mathrm{m}^{-3}$ was noticed under $120 \%$ from recommended $\mathrm{N}$ with deficit irrigation 0.8 $\mathrm{ET}_{\mathrm{c}}$ (Fig.14 B). Also, it is necessary and importantly to observe that WP value under irrigation with $100 \%$ from actual evapotranspiration $\left(1.0 \mathrm{ET}_{\mathrm{c}}\right)$ and $100 \%$ from recommended nitrogen fertilizer,1.8 $\mathrm{kg} \mathrm{m}^{-3}$ was quite like to that obtained under (120\%) $\mathrm{N}$ and deficit irrigation (0.7 $\mathrm{ET}_{\mathrm{c}}$ ), (Fig.14 B). It was also noticed from model simulations that the farmer wheat productivity $7.4 \mathrm{t} \mathrm{ha}^{-1}$ could be obtained by adding $80 \%$ from recommended doses of nitrogen fertilizer and 1.2 $\mathrm{ET}_{\mathrm{c}}$ as irrigation water applied, at this point WP will be $1.5 \mathrm{~kg} \mathrm{~m}^{-3}$. In arid and semi-arid 


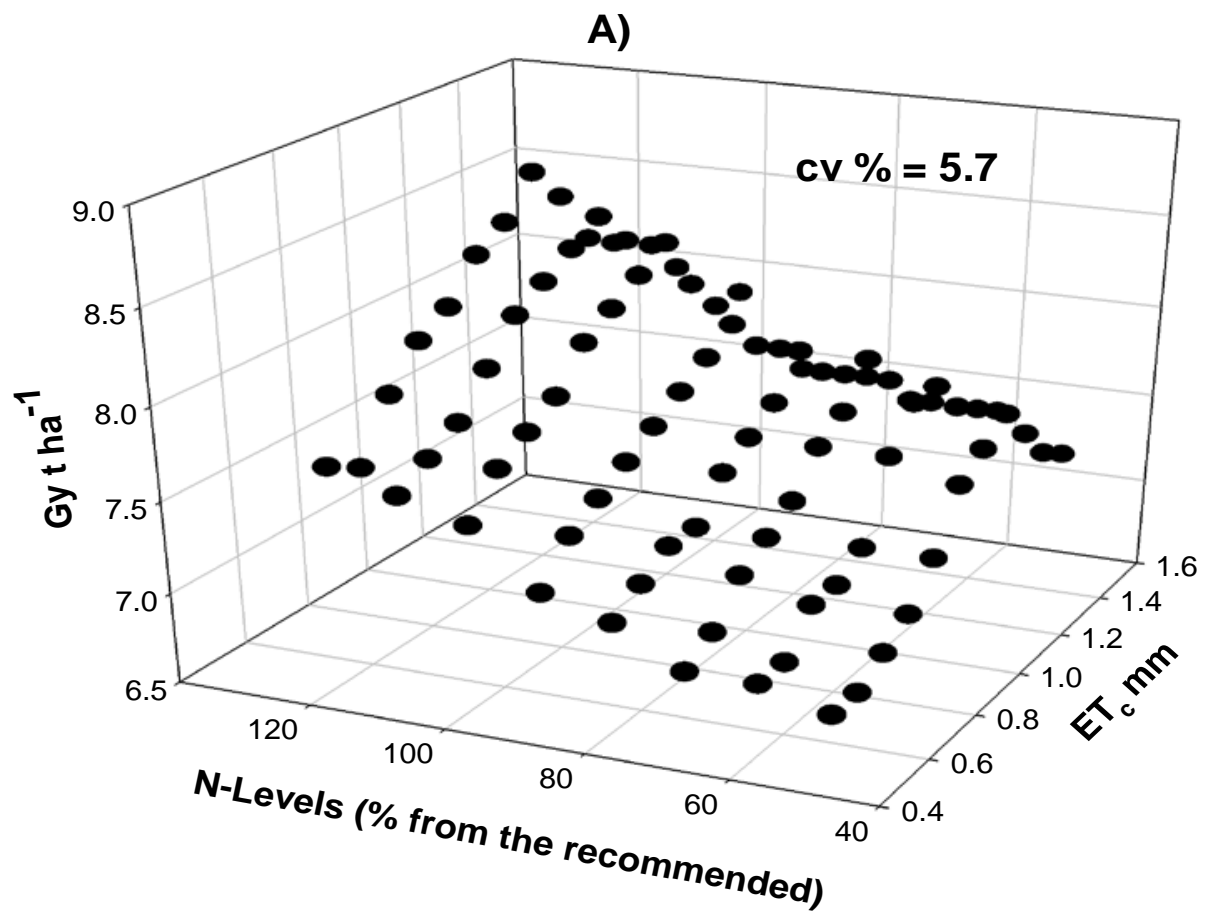

B)

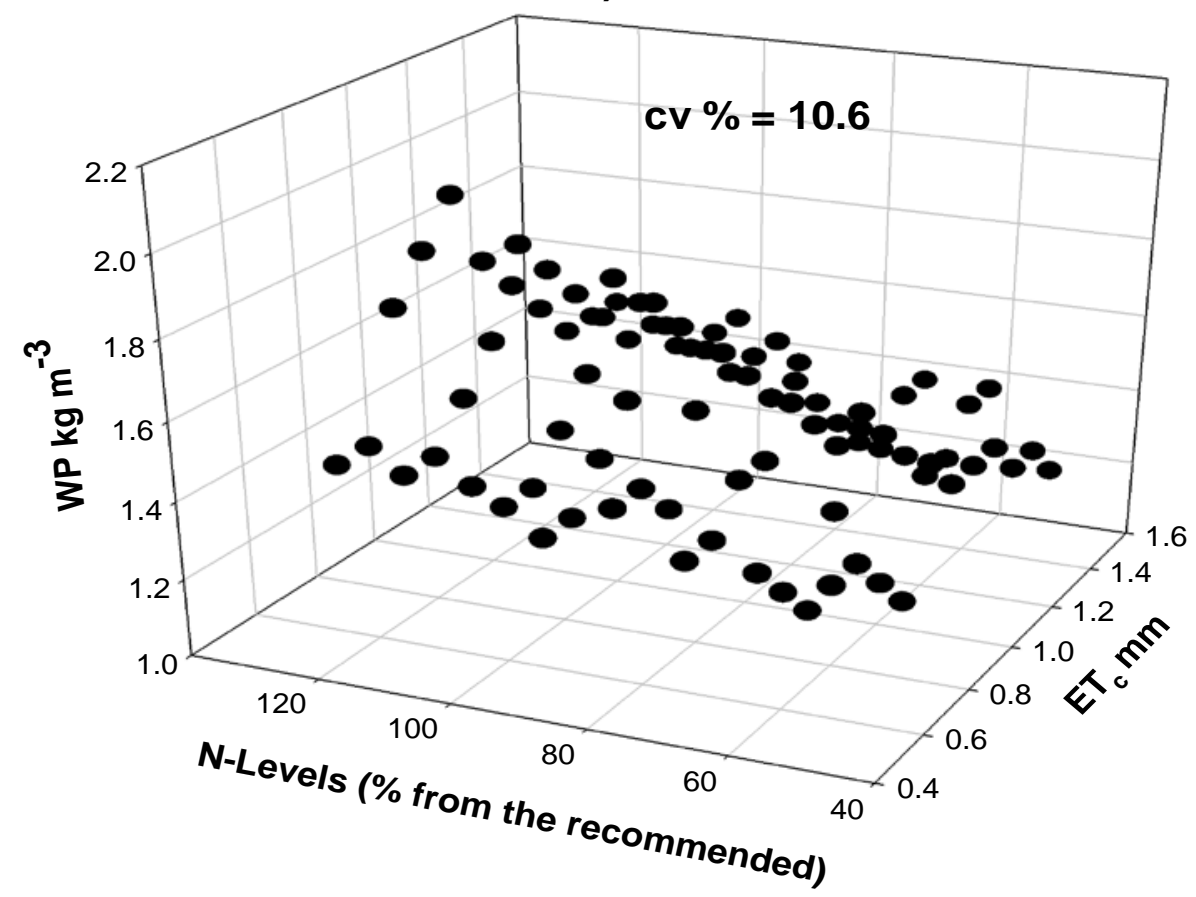

Fig. (14). Simulated grain yield (A) and water productivity (B) as an overall prediction of both models (Aquacrop and Apsim) under different water regime and $\mathrm{N}$ management scenarios. 
climate region like Egypt, where water resources are limited deficit irrigations could produce satisfactory and substantial yield provided that increase nitrogen dose. The study findings show an increase in WP under deficit irrigation. Consequently, combination between less water applied quantity and appropriate management of $\mathbf{N}$ fertilizer will increase wheat water productivity in the region. In conclusion, we have two recommended management practices from this study that can enhance wheat yield and water productivity. The first recommendation, which resulted from two growing seasons (field experiment) suppose that $\mathrm{N} 1 \quad(100 \%$ from recommended $\mathrm{N}$ combined with $9.2 \mathrm{t} \mathrm{ha}^{-1}$ compost) and 12 $\left(1.0 \mathrm{ET}_{\mathrm{c}}\right)$ gave the highest yield and water productivity. Meanwhile, the second recommendation which extracted from different predicted scenarios of water and $\mathrm{N}$ management, suppose that using (120\% from recommended $N$ ) in combination with $0.8 \quad \mathrm{ET}_{\mathrm{c}}$ gave the highest value of water productivity as predicted by both crop models. The first recommended treatment gave $8.2 \mathrm{t} \mathrm{ha}^{-1}$ of grain yield and $1.6 \mathrm{~kg} \mathrm{~m}^{-3}$ for WP. Meanwhile, the second treatment increased the yield to reach $8.5 \mathrm{t} \mathrm{ha}^{-1}$ and sharp increase in WP by $2.0 \mathrm{~kg} \mathrm{~m}^{-3}$.

Therefore, we have used the previous two main recommendations separately to predict wheat yield in all districts (11 sites) of the governorate (Figs 15 A \&B) and Table 8. Based on the World Reference Base for Soil Resources, the main soil group is Fluvisols (FI) with main texture clay and loamy clay (Taha, 2000) and (FAO, 1998). Meanwhile, climatic data for all locations were generated from NASA, AgCFSR climate dataset

(http://data.giss.nasa.gov/impacts/agmip cfl) and used for simulations, Fig.3.The overall wheat yield as predicted by two crop models using the first recommended treatments (Fig.15A) was slightly lesser than that predicted by the second recommended treatments (Fig.15 B). This is mainly attributed to increasing the nitrogen fertilizer dose in case of the second scenario $120 \%$ from recommended which equal $144 \mathrm{~kg} \mathrm{~N}$ ha ${ }^{1}$ and its role in maximizing the yield and irrigation with $0.8 \mathrm{ET}_{\mathrm{c}}$. Meanwhile, the first recommended treatment supposes adding $100 \%$ from recommended $\mathrm{N}$ combined with $9.2 \mathrm{t} \mathrm{ha}^{-1}$ from compost achieving $126.4 \mathrm{~kg} \mathrm{~N} \mathrm{ha}^{-1}$ with irrigation at $1.0 \mathrm{ET}_{\mathrm{c}}$. The studied districts that already cover the agricultural area in KFS are (Baltim, El-Hamoul, Metobus, El-Riad, Sidi Salem, Sidi Ghazy, Fewa, Biyala, Desouk, Miseer and Qillin). As demonstrated in (Figs $15 \mathrm{~A}$ \&B) that wheat yield decreased on the North direction and increasing towards the South direction, however temperature increase on the south trend. This is mainly attributed to increasing soil salinity which resulting from sea water intrusion in locations close to Mediterranean Sea, (Fig.1B.) Therefore, AQUACROP and APSIM-Wheat predicted the yield and maximized its value at the North delta of Egypt successfully. 

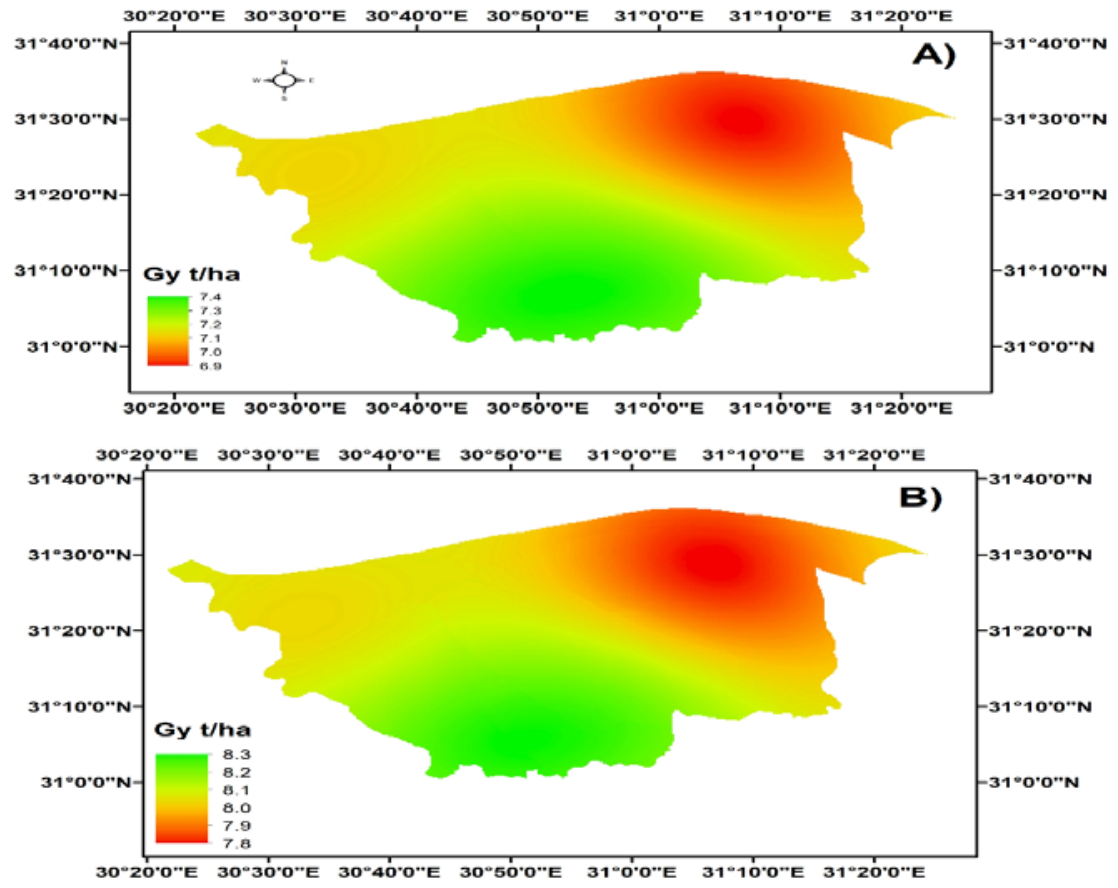

Fig. (15). Predicted wheat yield cross all wheat cultivated districts in Kafrelsheikh governorate as an overall of both models. A) represents the optimum treatments of irrigation (12) and fertilization (N1) that gave the highest yield under experiment conditions. B) represents the optimum treatments of irrigation $\left(\mathrm{I} 0.8 \mathrm{ET}_{\mathrm{c}}\right)$ and fertilization ( $\mathrm{N120} \%$ from recommended $\mathrm{N}$ ) that gave the highest yield under predicted scenarios. The data interpolated using the model outputs of 11 districts in the governorate (Table 8).

Table (8): Predicting wheat yield for different locations in the studied province using the calibrated AquaCrop and Apsim models under better treatments.

\begin{tabular}{lcccc}
\hline Location & Lat & Long & Gy t ha & Gy t ha $^{-1}$ * $^{-1}$ \\
\hline Baltim & 31.50 & 31.09 & 4.3 & 4.6 \\
El-Hamoul & 31.30 & 31.15 & 5.8 & 6.1 \\
Metobus & 31.30 & 30.60 & 6.3 & 6.5 \\
El-Riad & 31.30 & 30.94 & 7.6 & 8.1 \\
Sidi Salem & 31.27 & 30.78 & 7.5 & 8.0 \\
Sidi Ghazy & 31.20 & 31.10 & 8.1 & 8.7 \\
Fewa & 31.20 & 30.60 & 7.3 & 7.6 \\
Biyala & 31.17 & 31.22 & 7.0 & 7.5 \\
Desouk & 31.12 & 30.69 & 8.3 & 8.5 \\
Miseer & 31.18 & 31.04 & 8.1 & 8.7 \\
Qillin & 31.04 & 30.85 & 8.1 & 8.8 \\
& Stdev & & 1.2 & 1.3
\end{tabular}

*Simulated grain yield by average both models using the best treatments explored from the field experiment. Treatments here included adding $100 \%$ from recommended $\mathrm{N}$ along with $9.2 \mathrm{t} \mathrm{ha}^{-1}$ from compost achieving $126.4 \mathrm{~kg} \mathrm{~N} \mathrm{ha}^{-1}$ with irrigation at $1.0 \mathrm{ET}_{\mathrm{c}}$.

**Simulated grain yield by average both models using the best treatments explored from different scenarios. The treatments here are adding $120 \%$ from recommended dose which equal $144 \mathrm{~kg} \mathrm{Nha}$ ${ }^{1}$ and irrigation with $0.8 \mathrm{ET}_{\mathrm{c}}$. 


\section{CONCLUSION}

Wheat production in regions suffering from limited water resources like Egypt is influencing essentially by deficit irrigation, and nitrogen fertilization. In this study, APSIM-Wheat and AQUACROP showed a high accuracy in simulating anthesis date, maturity date, grain yield and total biomass. Where, the statistical indicators $R^{2}$, RMSD and $D$ confirmed such accuracy for both models. These models are used after that to predict yield and water productivity under various scenarios of irrigation and nitrogen fertilization. Generally, WP decreased with applied water increase, due to decreasing grain yield than ET increase. A field experiment conducted in two successive growing seasons demonstrated that the highest WP $1.6 \mathrm{~kg}$ $\mathrm{m}^{-3}$ was achieved under the recommended planting date (P2), the recommended nitrogen fertilizer combined with 9.2ton $\mathrm{ha}^{-1}$ of compost (N1) as well as using the actual evapotranspiration $1.0 \mathrm{ET}_{\mathrm{C}}$ as applied irrigation water (12). Different scenarios of irrigation and nitrogen fertilization were used as model inputs to explore the best option achieving the maximum water productivity. Consequently, the highest value of WP $2.0 \mathrm{~kg} \mathrm{~m}^{-3}$ was predicted by using $120 \%$ from recommended $\mathrm{N}$ and $0.8 \mathrm{ET}_{\mathrm{c}}$ as water application. Importantly, under all scenarios used of irrigation and fertilization, WP ranged $1.7-2.0 \mathrm{~kg} \mathrm{~m}^{-3}$, meanwhile grain yield ranged from 6.8 $8.7 \mathrm{t} \mathrm{ha}^{-1}$. This wide range was mainly attributed to the interaction effects of irrigation and fertilization on yield and WP. Noticeably, the farmers yield in North delta of Egypt $7.4 \mathrm{t} \mathrm{ha}^{-1}$ was predicted by adding $80 \%$ from recommended $\mathrm{N}$ and $1.4 \mathrm{ET}_{\mathrm{c}}$ as irrigation water resulted in lower value of WP $\mathbf{1 . 5}$ $\mathrm{kg} \mathrm{m}^{-3}$. Following the specifying of the best recommended options of irrigation and nitrogen fertilization in both field experiments and modeling prediction scenarios, we predicted the wheat yield in all districts in Kafrelsheikh governorate. APSIM-Wheat and AQUACROP models could be used as tool to predict and optimize wheat yield and water productivity under different treatments of irrigation and fertilization in Egypt.

\section{Acknowledgments}

The lead author is thankful to Agricultural Research Center (ARC); Soils, Water and Environment Research Institute (SWERI) for providing the financial support and research facilities.

\section{REFERENCES}

Abdel Kawy, W.A.M. and R.R. Ali (2012). Assessment of soil degradation and resilience at northeast Nile Delta, Egypt: The impact on soil productivity. The Egyptian Journal of Remote Sensing and Space Science, 15(1): 19-30.

Ahmed, M. et al. (2016). Calibration and validation of APSIM-Wheat and CERES-Wheat for spring wheat under rainfed conditions: Models evaluation and application. Computers and Electronics in Agriculture, 123: 384401.

Ali, M.H. and M.S.U. Talukder (2008). Increasing water productivity in crop production-Asynthesis. Agricultural Water Management 95: 1201-1213.

Archontoulis, S.V., F.E. Miguez and K.J. Moore (2014). A methodology and an optimization tool to calibrate phenology of short-day species included in the APSIM PLANT model: application to soybean. Environ. Modell. Softw, 62: 465-477.

Arora, V.K., H. Singh and B. Singh (2007). Analyzing wheat productivity responses to climatic, irrigation and fertilizer-nitrogen regimes in a semiarid sub-tropical environment using 
the CERES-Wheat model. Agric. Water Manage, 94(1-3): 22-30.

Asseng, S. et al., (2015). Rising temperatures reduce global wheat production. Nat Clim Change, 5(2): 143-147.

Asseng, S. et al., (1998a). Use of the APSIM wheat model to predict yield, drainage, and NO3 - leaching for a deep sand. Australian Journal of Experimental Agriculture, 49(3): 363378.

Asseng, S. et al., (2004). Simulated wheat growth affected by rising temperature,increased water deficit and elevated atmospheric $\mathrm{CO} 2$. . Field Crop Res, 85((2-3)): 85-102.

Asseng, S. et al., (1998). Performance of the APSIM-wheat model in western Australia? . Field Crops Res, 57(2): 163-179.

Asseng, S. et al., (1998b). Performance of the APSIM-wheat model in western australia. Field Crops Research, 57(2): 163-179.

Basso, B., L. Liu and J.T. Ritchie (2016). A comprehensive review of the CERES-Wheat, -Maize and -Rice models' performances. In: Donald, L.S. (Ed.). Advances in Agronomy: 27132.

Brisson, N. et al., (2003). An overview of the crop model STICS. Eur. J. Agron, 18(3-4): 309-332.

Ceglar, A.C., Z. Repinšek, L. KajfežBogataj and T. Pogačar, (2011). The simulation of phenological development in dynamic crop model: the Bayesian comparison of different methods. Agric. For. Meteorol, 151(1): 101-115.

Dettori, M., C. Cesaraccio, A. Motroni, D. Spano and P. Duce (2011). Using CERES-Wheat to simulate durum wheat production and phenology in Southern Sardinia. Field Crop Res, 120(1): 179-188.

Donatelli, M., M.K. Van Ittersum, M. Bindi and J.R. Porter (2002). Modelling cropping systems-highlights of the symposium and preface to the special issues. Eur. J. Agron, 18(1-2): 1-11.

Dong, C., D. Hu, Y. Fu, M. Wang and H. Liu (2014). Analysis and optimization of the effect of light and nutrient solution on wheat growth and development using an inverse system model strategy. Comput. Electr. Agric, 109: 221-231.

FAO, (1998). World Reference Base for Soil Resources. Rep.84. Rome.

Franklin, D., D. Bender-Özenç, N. Özenç and M. Cabrera (2015). Nitrogen mineralization and phosphorus release from composts and soil conditioners found in the Southeastern United States. Soil Sci. Soc. Am. J., 79: 1386-1395.

Godwin, D.C. and U. Singh (1998). Nitrogen balance and crop response to nitrogen in upland and lowland cropping systems. In: Tsuji, G., Hoogenboom, G., Thornton,P. (Eds.),. Understanding Options for Agricultural Production. Springer,Netherlands: 55-77.

Hargreaves, J., M. Adl, P.A. Warman and A.E. Environ (2008). review of the use of composted municipal solid waste in agriculture., 123: 1-14.

Heimovaara, T.J., J.A. Huisman, J.A. Vrugt and W. Bouten (2004). Obtaining the spatial distribution of water content along a TDR probe using the SCEM-UA bayesian inverse modeling scheme. Vadose Zone Journal 3: 128 145.

Holzworth, D.P. et al., (2014). APSIM evolution towards a new generation of agricultural systems simulation. Environ. Modell. Software, 62: 327350.

Hsiao, T.C. et al. (2009). AquaCrop-the FAO crop model to simulate yield response to water: III. Parameterization and testing for maize. Agron. J, 101: 448-459. 
Jacovides, C.P. and H. Kontoyiannis (1995). Statistical procedures for the evaluation of evapotranspiration computing models. Agricultural Water Management 27(3-4): 365-371.

Jones, J.W. et al. (2003). The DSSAT cropping system model? Eur. J. Agron, 18(3-4): 235-265.

Keating, B.A. et al. (2003). An overview of APSIM: a model designed for farming systems simulation. Eur.J. Agron, 18(3-4): 267-288.

Khoshravesh, M., B. Mostafazadeh-Fard, M. Heidarpour and A.R. Kiani (2013). AquaCrop model simulation under different irrigation water and nitrogen strategies. Water Sci Technol 67: 232238.

Kijne, J.W., R. Barker and D. Molden (2003). Water Productivity in Agriculture: Limits and Opportunities for Improvement. Comprehensive Assessment of Water Management in Agriculture Series, No. 1 International Water Management Institute, Srilanka.

Klute, A. (1986). Methods of Soil Analysis. . Part I-Physical and Mineralogical Methods. , Second Edition.

Kumar, P., A. Sarangi, D.K. Singh and S.S. Parihar (2014). Evaluation of AquaCrop model in predicting wheat yield and water productivity under irrigated saline regimes. Irrig Drain 63: 474-487.

Ma, L. et al., (2011). A Protocol for Parameterization and Calibration of RZWQM2 in Field Research. In: Ahuja, L.R., Ma, L. (Eds.). Methods of Introducing System Models into Agricultural Research. Am Society Agron, Crop Science Society of America, Soil Science Society of America: 1-64.

Martre, P. et al., (2015). Multimodel ensembles of wheat growth: many models are better than one. Glob. Change Biol. , 21(2): 911-925.
Mhizha, T., S. Geerts, E. Vanuytrecht, A. Makarau and D. Raes (2014). Use of the FAO AquaCrop model in developing sowing guidelines for rainfed maize in Zimbabwe. Water SA, 40: 233-244.

Moriasi, D.N. et al., (2007). Model evaluation guidelines for systematic quantification of accuracy in watershed simulations. Transactions of the ASABE, 50(3): 885-900.

Olesen, J.E. et al., (2012). Changes in time of sowing, flowering and maturity of cereals in Europe under climate change. Food Addit Contam Part A Chem Anal Control Expo Risk Assess. , 29(10): 1527-1542.

Page, A.L., R.H. Miller and D. Keeney (1982). Methods of Soil Analysis. Part 2, Chemical and Microbiological Properties, Agronomy Series No 9, American Society of Agronomy,Madison, WI.

Paredes, P., J.P. de Melo-Abreu, I. Alves and L.S. Pereira (2014). Assessing the performance of the FAO AquaCrop model to estimate maize yields and water use under full and deficit irrigation with focus on model parameterization. Agric Water Manag, 144: 81-97.

Prasad, M.A. (2009). Literature Review on the Availability of Nitrogen from Compost in Relation to the Nitrate Regulations. Environment Protection Agency: Wexford, Ireland, SI 378

Ritchie, J.T., U. Singh, D. Godwin and W.T. Bowen (1998). Cereal growth, development, and yield. In: Tsuji, G.Y., Hoogenboom, G., Thornton, P.K. (Eds.), Understanding Options for Agricultural Production. The Netherlands: Kluwer Academic, Dordrecht: 79-98.

Robertson, M.J. et al., (2002). Simulation of growth and development of diverse legume species inAPSIM. Aust. J. Agric. Res, 53(4): 429-446. 
Saad, A.M. M. M.G. and G.A. El-Sanat (2014). Evaluating AquaCrop model to improve crop water productivity at North Delta soils, Egypt. Advances in Applied Science Research, 5(5): 293304.

Steduto, P., T.C. Hsiao, E. Fereres and D. Raes (2012). Crop Yield Response to Water. FAO Irrigation and Drainage paper 66(FAO, Rome, Italy): 500.

Sullivan, D. et al., (2003). itrogen availability seven years after a highrate food waste compost application. Compos. Sci. Util, 11: 265-275.

Sullivan, D., A. Bary, D. Thomas, S. Fransen and C. Cogger (2002). Food waste compost effects on fertilizer nitrogen efficiency, available nitrogen, and tall fescue yield. Soil Sci. Soc. Am. J., 66: 154-161.

Taha, M.H. (2000). Soil fertility management in Egypt. Regional Workshop on Soil Fertility Management Through Farmer Field Schools in the Near East,Amman, Jordan,: 2-5.

Tubiello, F.N. and F. Ewert (2002). Simulating the effects of elevated $\mathrm{CO} 2$ on crops: approaches and applications for climate change. Eur J Agron, 18(1): 57-74.

USDA, (2010). Keys to soil taxonomy. United State Department of
Agriculture: Natural Resources Conservation Service (NRCS) third edition.

Wang, E. et al., (2003). The new APSIMWheat model: Performance and future improvements.In: Unkovich, M., O'Leary,

G. (Eds.). Proceedings of the 11th Australian Agronomy Conference. Australian Society of Agronomy, Geelong Victoria.

Wang, X.C., J. Li, M.N. Tahir and X.Y. Fang (2012). Validation of the EPIC model and its utilization to research the sustainable recovery of soil desiccation after alfalfa (Medicago sativa L.) by grain crop rotation system in the semi-humid region of the Loess Plateau. Agric. Ecosyst. Environ, 161: 152-160.

Willmott, C.J. (1984). On the evaluation of model performance in physical geography. In Spatial Statistics and Models, Gaile GL, Willmott CJ (eds). D. Reidel: Boston: 443-460.

Zhang, H., T.Y. Oweis, S. Garabet and M. Pala (1998). Water-use efficiency and transpiration efficiency of wheat under rain-fed conditions and supplemental irrigation in a Mediterranean-type environment. Plant Soil 201: 295-305. 
تعظيم انتاجيه القمح والانتاجيه المائيه باستخدام النماذج الرياضيه الاكواكروب و الابسيم في شمال دلتا النيل - مصر

احمد محمد سعد خيز، ملحت جابر زغدان ، محمود ابوالفتوح عياد، سحر حسن راشد

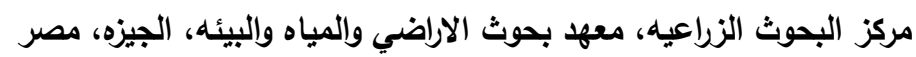

الملخص العربي

تم اختبار صلاحيه نوعين من اهم النماذج الرياضيه الحديثه وذلك مع صفات زمن التزهير، زمن النضج، محصول

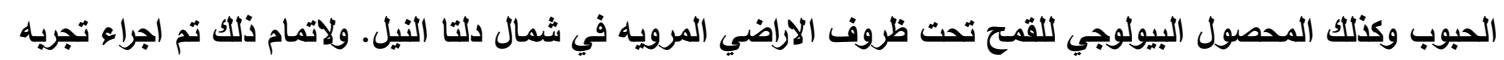

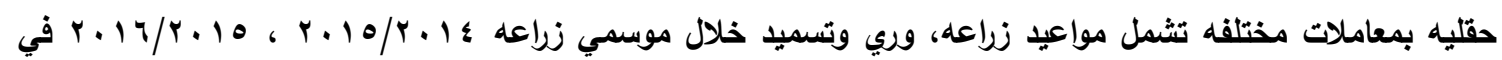

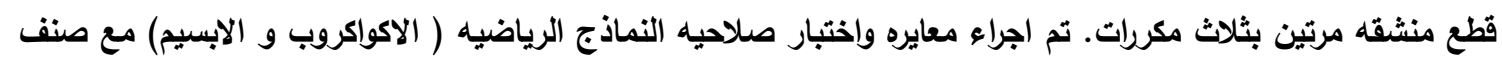

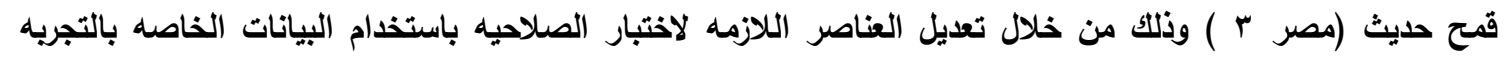
الحقليه. تم التأكد من صلاحيه استخدام هذه النماذج الرياضيه في التنبؤ من خلال الوصول الي اعلي قيمه لكلا من

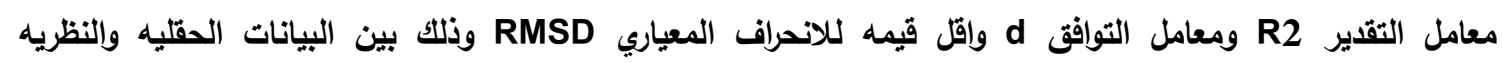
(المتببء بها) اثثاء عمليه المعايره. عقب اختبار صلاحيه هذه النماذج ، تم استخذامها للتنبؤ بأعلي انتاجيه للقمح وكنلك اعلي قيمه لانتاجيه وحده المياه من خلال استخدام عده سيناريوهات من كميات مياه الري المضافه والتسميد

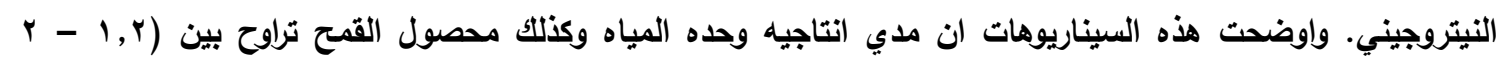

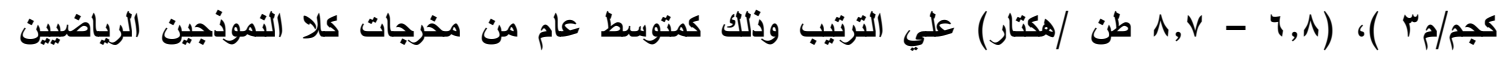

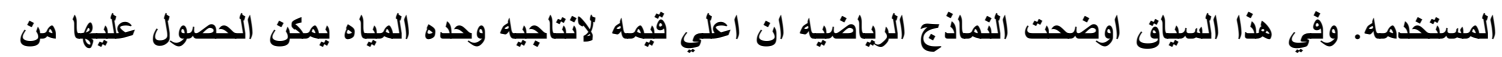

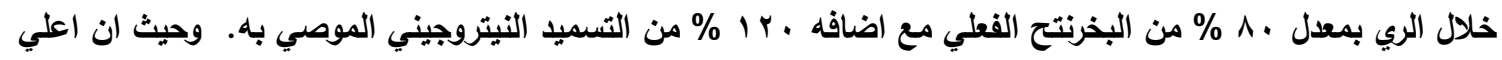

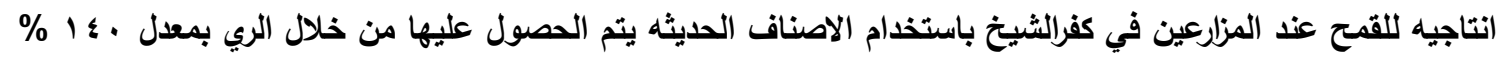

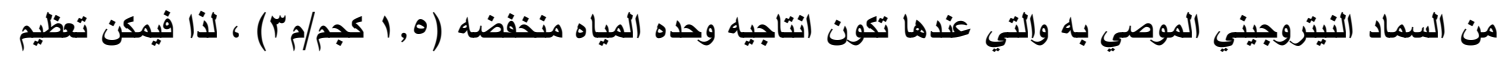

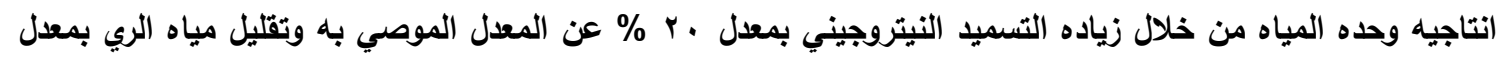

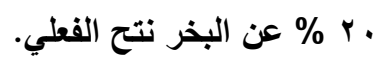
ايضا تم استخدام هذه النماذج الرياضيه للتنبؤ بانتاجيه القمح في المراكز الاخري في محافظه كفرالثيخ وذلك لامكانيه

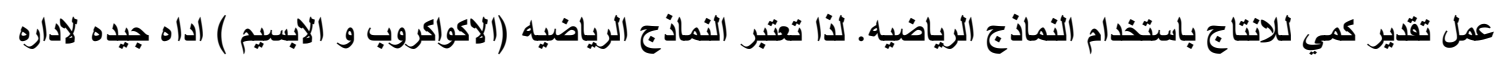
المياه والتسميد تحت ظروف الاراضي المصريه. 
A.M.S. Kheir, et al., 